\title{
Palynological Studies of the Coals of the Princess Reserve District
}

in Northeastern Kentucky

GEOLOGICAL SURVEY PROFESSIONAL PAPER 839 Work done in cooperation with the Kentucky Geological Survey

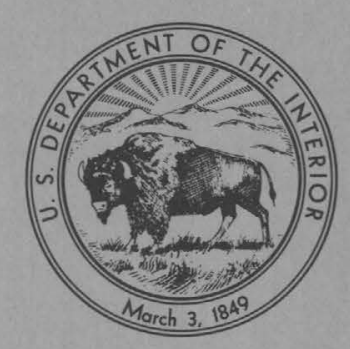





\section{Palynological Studies of the Coals}

\section{of the Princess Reserve District}

\section{in Northeastern Kentucky}

By ROBERT M. KOSANKE

GEOLOGICAL SURVEY PROFESIONAL PAPER 839

Work done in cooperation with the

Kentucky Geological Survey

$A$ discussion of the spore and pollen assemblages, range zones, and coal correlations

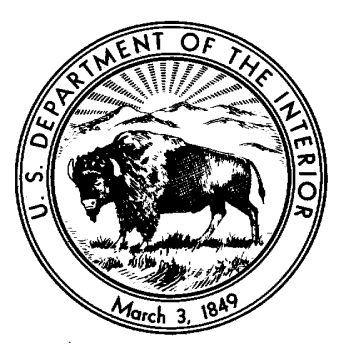

UNITED STATES GOVERNMENT PRINTING OFFICE, WASHINGTON : 1973 
UNITED STATES DEPARTMENT OF THE INTERIOR

ROGERS C. B. MORTON, Secretary

GEOLOGICAL SURVEY

V. E. McKelvey, Director

Library of Congress catalog-card No. 73-600287

For sale by the Superintendent of Documents, U.S. Government Printing Office

Washington, D.C. 20402 - Price $\$ 1.00$ (paper cover)

Stock Number 2401-02460 


\section{CONTENTS}

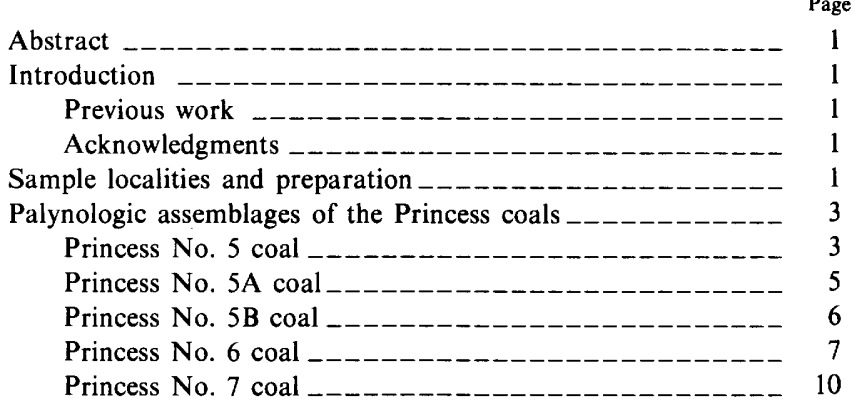

Palynologic assemblages of the Princess coals - Continued Princess No. 8 (?) coal _-_ Princess No. 9(?) coal Brush Creek(?) coal__--_--_---_-_--_--_-_--_-- 10

Zosterosporites, n. gen. -

Correlation of the Princess coals _._. 12

Interregional coal correlations _______-__-__-_- 17

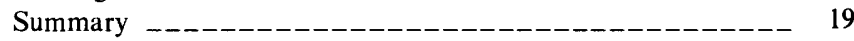

References cited _._.

Index _._ 21

\section{ILLUSTRATIONS}

[Plate follows index]

PlATE 1. Zosterosporites triangularis, n. gen., n. sp., and selected taxa.

FIGURE 1. Location map of the Princess reserve district

2. Coal logs of the Webbville 1 core hole and two outcrop samples

3. Chart showing stratigraphic distribution of genera and species

4. Diagram showing abundance of selected genera and species observed in the Princess No. 5 through No. 7 coals

5. Diagrammatic reconstruction of Zosterosporites triangularis, n gen. $\mathrm{n}$. $\mathrm{sp}$.

$\begin{array}{lll}\text { 5. Diagrammatic reconstruction of Zosterosporites triangularis, n. gen., n. sp. }------ & 12 \\ \text { 6. Diagram showing range zones of selected taxa } & \end{array}$

\section{TABLES}

TABLES 1 - 9. Percentage of genera of small spores in:

1. Princess No. 5 coal

2. Princess No. $5 \mathrm{~A}$ coal

3. Princess No. 5B coal

4. Princess No. 6 coal (from drill core)

5. Princess No. 6 coal (from roadcut)

6. Princess No. 7 coal (from drill core)

7. Princess No. 7 coal (from roadcut)

8. Lower bench Richardson coal at the type locality, Milo quadrangle, Kentucky

9. Skyline coal from the type locality 



\title{
PALYNOLOGICAL STUDIES OF THE COALS OF THE
}

\section{PRINCESS RESERVE DISTRICT IN NORTHEASTERN KENTUCKY}

\author{
By Robert M. KosAnKe
}

\begin{abstract}
Palynological studies of Pennsylvanian coals and associated strata from eastern Kentucky have resulted in establishing of range zones of numerous taxa. Some of these taxa have restricted range zones that are useful in correlation studies of coals in the Princess reserve district. The coal nomenclature is, in part, peculiar to this district, corresponding neither to that used to the north and east in Ohio and West Virginia nor to that of other coal reserve districts in eastern Kentucky. Correlations of some of these coals with those in other areas have been proposed by several authors. These correlations are, for the most part, based on stratigraphic intervals measured from marker horizons or are based on geologic mapping.

The coals under consideration are the Princess No. 5 through the Brush Creek(?) coal. This interval extends from the upper Breathitt Formation to the lower Conemaugh Formation. Samples of the Princess Nos. 5-7 coals were obtained from a diamond-drill core. Outcrop samples of the Princess No. 6 through the Brush Creek(?) coals were also used. Within the interval of the Princess No. 5 through the Brush Creek(?) coals, several major palynological events occur. These include the diminution and extinction of Densosporites, the peak occurrence of Torispora, and the entire range zones of Laevigatosporites pseudothiessenii and Schopfites dimorphus. Zosterosporites is a new fossil spore genus and is described from seat-rock samples of the Princess No. 5B coal.

The Princess No. 5 coal from the Webbville 1 core hole is less than 10 inches thick, but, palynologically, it is similar in part to the Richardson and Skyline coals. The Princess Nos. 6 and 7 coals of northeastern Kentucky are correlated with the Lower and Middle Kittanning coals of Ohio and Pennsylvania. The Lower Kittanning-Princess No. 6 coal is similar palynologically to the Colchester (No. 2) coal of Illinois. The Middle Kittanning-Princess No. 7 coal may be as old as the Springfield (No. 5) coal or may be somewhat younger and related to the Briar Hill (No. 5A) coal of Illinois, if differences in abundance ratios are not regarded as important.
\end{abstract}

\section{INTRODUCTION}

The Princess reserve district, as reported by Ferm (1963), is located in the northern part of the eastern Kentucky coal field within the highly dissected Kanawha section of the Appalachian Plateau province. This district is bordered by Ohio to the north and by West Virginia to the east, and Grayson, Ky., is near the middle of the district. Boyd, Carter, Greenup, and Lawrence Counties and the eastern part of Lewis County are within the district, an area of about 1,350 square miles (fig. 1). The district name comes from the small mining community of Princess, in northwestern Boyd County.

Samples for this investigation were obtained from the Webbville 1 diamond-drill hole, which is near the center of Webbville quadrangle, southeast of Grayson in Lawrence
County, about 3 miles east of Webbville, Ky. The stratigraphic position of these samples with respect to each other is thus assured, and they are utilized as a reference set of samples. The samples investigated are from the Princess Nos. 5, 5A, 5B, 6, and 7 coals, together with those from the associated roof and seat rock. A second set of samples was collected from the south side of the roadcut of Interstate 64 in Rush quadrangle about 2,000 feet south of Coalton, or just $2 \frac{1}{2}$ miles north-northeast of Rush, Ky. The roadcut samples include the Princess Nos. 6 and 7 coals, together with three badly weathered younger coals.

\section{PREVIOUS WORK}

Palynological investigations of the coals of the stratigraphic interval under consideration have been intensively studied in the United States by several individuals. A few of these people are Schopf (1938), Kosanke (1947, 1950, 1964), Schemel (1951), Guennel (1952, 1958), Winslow (1959), Habib (1966), Gray (1967), Gray and Taylor (1967), and Peppers (1970). Because of these investigations very few new taxa remain to be described, although the usual emendations and new combinations are to be expected. One new taxon, Zosterosporites triangularis is described in this report. Z. triangularis is known from the roof rock of the Princess No. 5 coal and from the seat rock of the Princess No. 5B coal in the Princess reserve district of Kentucky.

\section{ACKNOWLEDGMENTS}

Don E. Wolcott assisted in the collection of the Princess samples, W. F. Outerbridge and E. C. Jenkins collected the Richardson coal samples, Charles L. Rice collected the Skyline coal samples, Norma L. Noble prepared the samples, and Wendell A. Martz took some of the photomicrographs used in this paper. This help is gratefully acknowledged.

\section{SAMPLE LOCALITIES AND PREPARATION}

Sixty-two samples of coal, roof rock, partings, and seat rock were collected and prepared for palynological investigation. All samples were collected in as similar a manner as possible. Core samples were cut with a carborundum saw so that a continuous ribbon of coal was obtained for maceration. Similarly, all outcrop samples were 


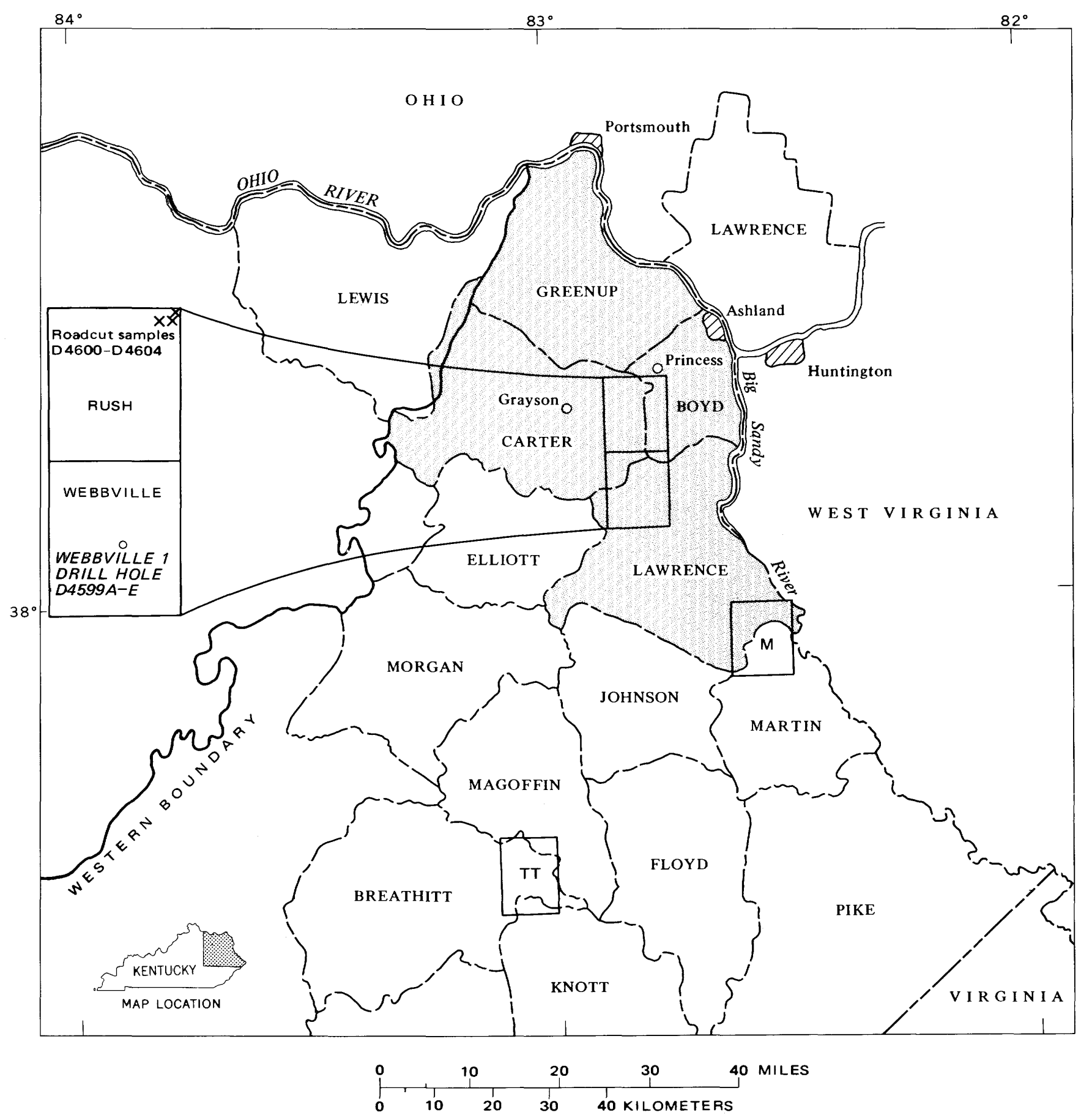

FIgURE 1. - The Princess reserve district (patterned) of northeastern Kentucky in the eastern Kentucky coal field. Locations of roadcut and diamond-drill samples in the Rush and Webbville quadrangles are shown in insert. Positions of the Milo (M) quadrangle from which samples of the Richardson coal were obtained and the Tiptop (TT) quadrangle from which samples of the Skyline coal were obtained are shown in outline.

collected as chiseled cubes to obtain as uniform and representative samples as possible.

Thirty samples were collected from the Webbville 1 diamond-drill hole. This diamond-drill hole is located as shown by Carlson (1971), on Little Cat Branch west of Baker School, 24,200 feet FNL $\times 16,500$ feet FEL of
Webbville quadrangle, Lawrence County, Ky. Five coals and associated strata were assigned U.S. Geological Survey Paleobotanical locality numbers D4599-A-E and laboratory maceration numbers $238-\mathrm{A}-\mathrm{CC}$, as follows:

Princess No. 5 coal, D4599-A (interval, $312 \mathrm{ft} 3 \mathrm{in.}-313 \mathrm{ft} 11 \frac{3 / 8}{\mathrm{in} . \text { ), }}$ macerations $238-\mathrm{Y}-\mathrm{CC}$; 
Princess No. 5A coal, D4599-B (interval, $292 \mathrm{ft} 43 / 16$ in. $-294 \mathrm{ft} 9^{11} / 16$ in.), macerations $238-\mathrm{P}-\mathrm{X}$;

Princess No. 5B coal, D4599-C (interval, $281 \mathrm{ft} 6 \% / 8$ in. $-284 \mathrm{ft} 67 / 8$ in.), macerations $238-\mathrm{J}-\mathrm{O}$;

Princess No. 6 coal, D4599-D (interval, $226 \mathrm{ft} 7 / 8$ in. $-229 \mathrm{ft} 9$ in.), macerations $238-\mathrm{E}-\mathrm{I}$; and

Princess No. 7 coal, D4599-E (interval, $190 \mathrm{ft}-192 \mathrm{ft} 57 \%$ in.), macerations $238-\mathrm{A}-\mathrm{D}$.

Thirty-two samples were collected from roadcut exposures on the south side in Interstate 64 in Rush quadrangle, Boyd County, Ky. These samples consist of the Princess Nos. 6, 7, 8(?), and 9(?) and the Brush Creek(?) coals. The following U.S. Geological Survey Paleobotanical locality and maceration numbers were assigned to these coals:

Princess No. 6 coal, D4600 (3,600 ft FEL $\times 3,200 \mathrm{ft} F N L)$, macerations $161-\mathrm{A}-\mathrm{J}$.

Princess No. 7 coal, D4601 (1,800 ft FEL $\times 2,900 \mathrm{ft} \mathrm{FNL})$, macerations 160-A-G;

Princess No. 8(?) coal, D4602 (1,200 ft FEL $\times 2,700 \mathrm{ft}$ FNL), macerations 162-A-C;

Princess No. 9(?) coal, D4603 (1,200 ft FEL $\times 2,700 \mathrm{ft}$ FNL), macerations 163-A-H; and

Brush Creek(?) coal, D4604 (1,100 ft FEL $\times 2,700 \mathrm{ft}$ FNL), macerations 164-A-D.

The coal samples were prepared according to the procedures described by Kosanke (1950), but with minor modifications, to achieve the most satisfactory preparations. The roof, seat-rock, and parting samples were prepared in the standard way for noncoal samples - that is, treatment with $\mathrm{HCl}, \mathrm{HF}, \mathrm{HNO}_{3}+\mathrm{KClO}_{3}$ and $\mathrm{KOH}$ and ultimately specific gravity separation with zinc bromide. Mounting of all maceration residues was made with Canada balsam. Precise preparation methods used for each maceration are recorded in maceration books 4 and 6 .

Abundance counts were made by uniform procedure. Two hundred fifty specimens were counted from each sample, and all taxa not observed in the count were then recorded. Five to 10 slides were examined for each maceration.

\section{PALYNOLOGIC ASSEMBLAGES OF THE PRINCESS COALS}

PRINCESS NO. 5 COAL

The coal between 312 feet 6 inches and 313 feet $83 / 8$ inches in the Webbville 1 core hole is considered to be the No. 5 coal. Figure $2 A$ graphically illustrates the interval from 312 feet 3 inches through 313 feet $11 \frac{3 / 8}{\text { inches. The total coal }}$ thickness is $93 / 8$ inches $(238-Z, 238-B B)$; in this coal the following genera are numerically significant:

Princess No. 5 coal

\begin{tabular}{|c|c|}
\hline \multicolumn{2}{|l|}{ Princess No. 5 coal } \\
\hline Genus & $\begin{array}{l}\text { Percent of } \\
\text { total count }\end{array}$ \\
\hline Laevigatosporites & 27.3 \\
\hline Lycospora & 23.7 \\
\hline Torispora _-_-_-_-_-_-_- & 15.3 \\
\hline Triquitrites_-_-_--_-_-_-_- & 8.6 \\
\hline Endosporites _-_--_-_-_-_-_-_ & 6.3 \\
\hline Granulatisporites & 4.3 \\
\hline Total & $\overline{85.5}$ \\
\hline
\end{tabular}

TABLE 1. - Percentage of genera of small spores in the Princess No. 5 coal [At a depth of $312 \mathrm{ft} 3$ in. to $313 \mathrm{ft} 11^{3 / 8}$ in, Webbville 1 core, on Little Cat Branch about 1.4 miles west of Baker School, 24,200 ft FNL $\times 16,500 \mathrm{ft} \mathrm{FEL}$, Webbville quadrangle, Lawrence County, Peced statistical count, or statistical count not attempted]

\begin{tabular}{|c|c|c|c|c|c|}
\hline \multirow{2}{*}{$\begin{array}{l}\text { Genus } \\
\text { Maceration No. }\end{array}$} & \multicolumn{5}{|c|}{ Percent } \\
\hline & $238-Y$ & $238-Z$ & $238-\mathrm{AA}$ & $238-B B$ & $238-\mathrm{CC}$ \\
\hline Ahrensisporites_-- & ---- & + & ---- & --- & --- \\
\hline Calamospora & + & 2.8 & 0.8 & 0.8 & + \\
\hline Cirratriradites _-_ & + & 2.4 & .8 & .4 & + \\
\hline Crassispora _-_-_- & + & ---- & .8 & ---- & + \\
\hline Cristatisporites _-_ & ---- & ---- & ---- & ---- & + \\
\hline Densosporites___. & --- & ---- & + & .8 & + \\
\hline Endosporites ____ & ---- & 3.6 & + & 10.4 & + \\
\hline Florinites _------ & + & 3.2 & 1.6 & .8 & + \\
\hline Granulatisporites - & + & 6.8 & 4.8 & .8 & + \\
\hline Laevigatosporites - & + & 28.0 & 29.6 & 26.4 & + \\
\hline Lycospora _-_-_- & + & 6.0 & 30.8 & 50.4 & + \\
\hline Murospora _-_-_ & + & 1.6 & ---- & ---- & ---- \\
\hline Punctatisporites - & + & 3.2 & 1.6 & 2.8 & ---- \\
\hline Raistrickia _--_-_ & + & .4 & .4 & ---- & + \\
\hline Reinschospora --- & ---- & ---- & --- & ---- & + \\
\hline Savitrisporites _-- & ---- & ---- & .4 & ---- & + \\
\hline Simozonotriletes _- & ---- & ---- & $-\ldots$ & ---- & + \\
\hline Torispora _-_-_- & + & 23.2 & 23.6 & 3.6 & + \\
\hline Triquitrites & + & 13.6 & 3.2 & 1.2 & + \\
\hline Vestispora _____- & ---- & + & + & ---- & + \\
\hline Wilsonites _-_-_-_ & --- & 1.2 & .8 & ---- & ---- \\
\hline Zosterosporites _-_ & + & ---- & ---- & ---- & ---- \\
\hline Monosaccates _-_-_ & --- & 4.0 & .8 & 1.6 & ---- \\
\hline All other taxa _--- & + & + & ---- & ---- & ---- \\
\hline Total__---_ & ---- & 100.0 & 100.0 & 100.0 & --- \\
\hline
\end{tabular}

DESCRIPTION OF MATERIAL IN MACERATIONS

$238-\mathrm{Y}-\mathrm{CC}, 20 \% \frac{1}{8}$ inches siltstone, shale, coal, and seat rock

$238-\mathrm{Y}, 3$ inches light-gray siltstone and medium-gray shale.

$238-Z, 5 \%$ inches coal.

$238-\mathrm{AA}, 51 / 2$ inches dark-gray to black shale and vitrain
$238-\mathrm{BB}, 3^{3 / 4}$ inches coal.

238 - CC, 3 inches seat rock - clay-shale.

Table 1 records the presence only or the abundance in the Princess No. 5 coal of 22 genera, including Simozonotriletes and Savitrisporites, which have not been observed in younger coals examined in this study. Comparison of the percentages of the numerically significant genera shown in table 1 for $238-\mathrm{Z}-\mathrm{BB}$ shows that Laevigatosporites is present at a uniform rate of 26.4 to 29.6 percent whereas Lycospora varies from 6 to 50.4 percent in this same interval. Laevigatosporites and Lycospora are of nearly equal abundance and represent more than half the spore-pollen population. Torispora averages 15.3 percent of the spore population of the Princess No. 5 coal samples. This occurrence represents the maximum abundance for the genus recorded so far from eastern Kentucky coals. Torispora and Triquitrites decrease in abundance from $238-\mathrm{Z}$ to 238-BB. Triquitrites and Endosporites, occurring at the rate of more than 8 and 6 percent respectively, help characterize this coal. All the species identified from the 

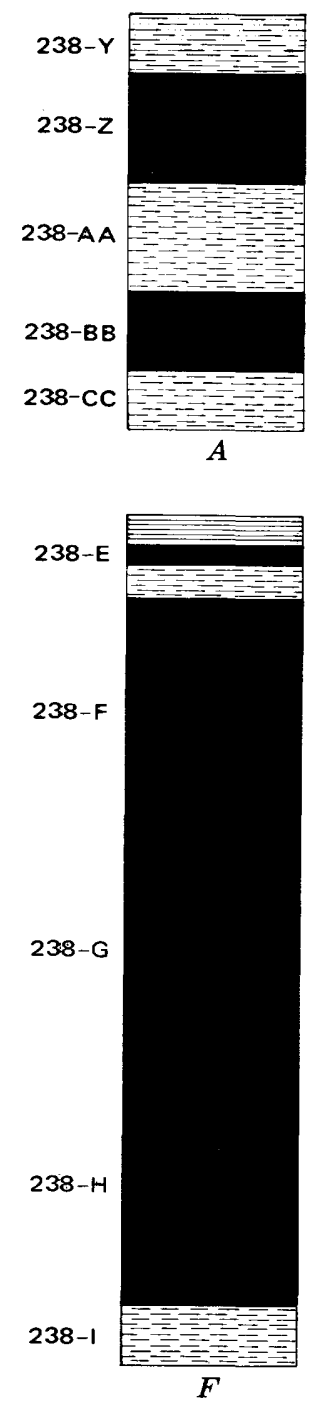
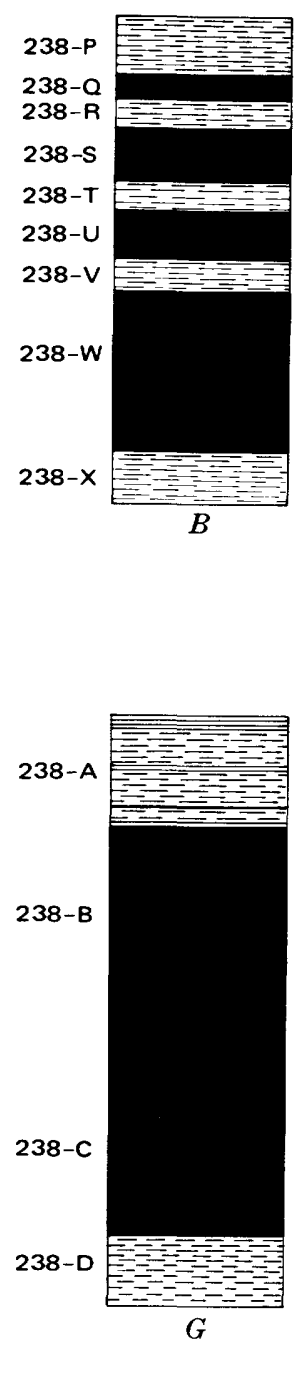

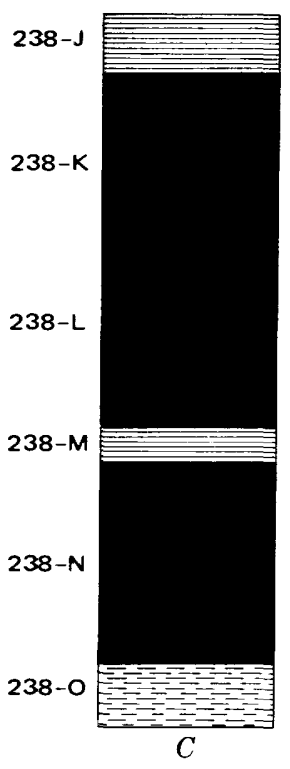

\section{EXPLANATION}

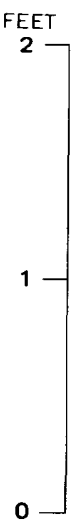

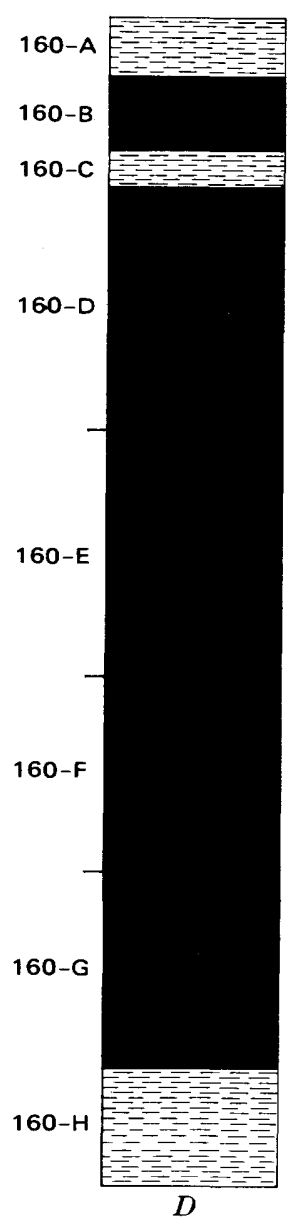

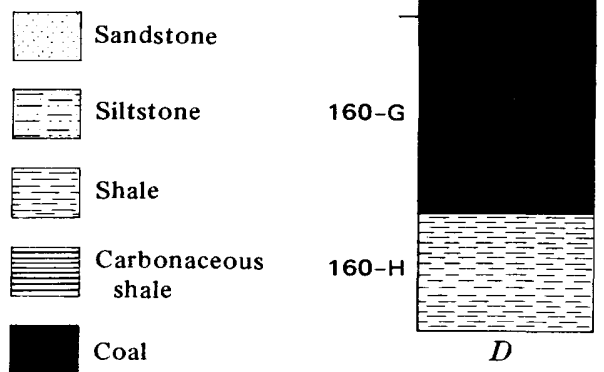

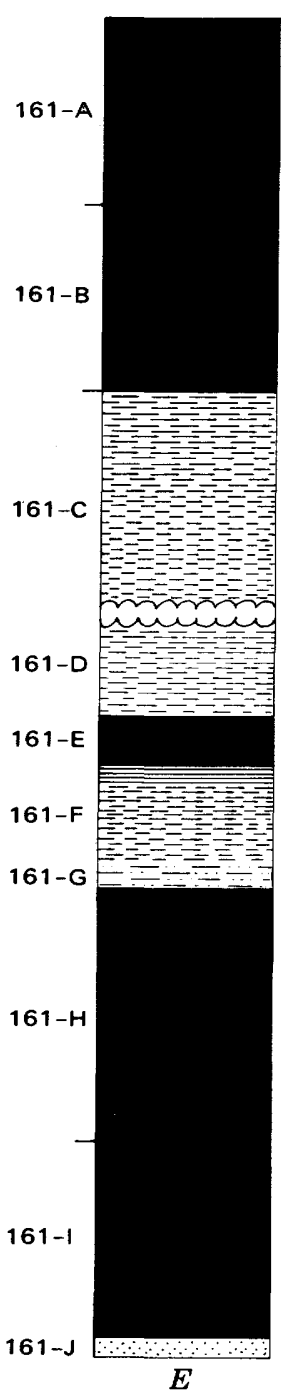

FIGURE 2. - Coal logs of samples prepared from the Webbville 1 diamond-drill hole $(A-C, F, G)$ and two outcrop samples $(D, E)$. The sample maceration numbers are given at the left of each coal log except for a thin lens of shale in $238-\mathrm{H}$ which was macerated separately and designated " $238-\mathrm{H}$ shale."

TAXA

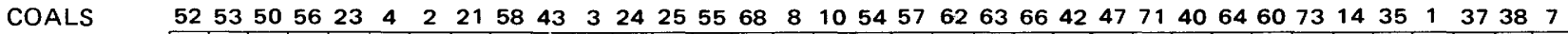

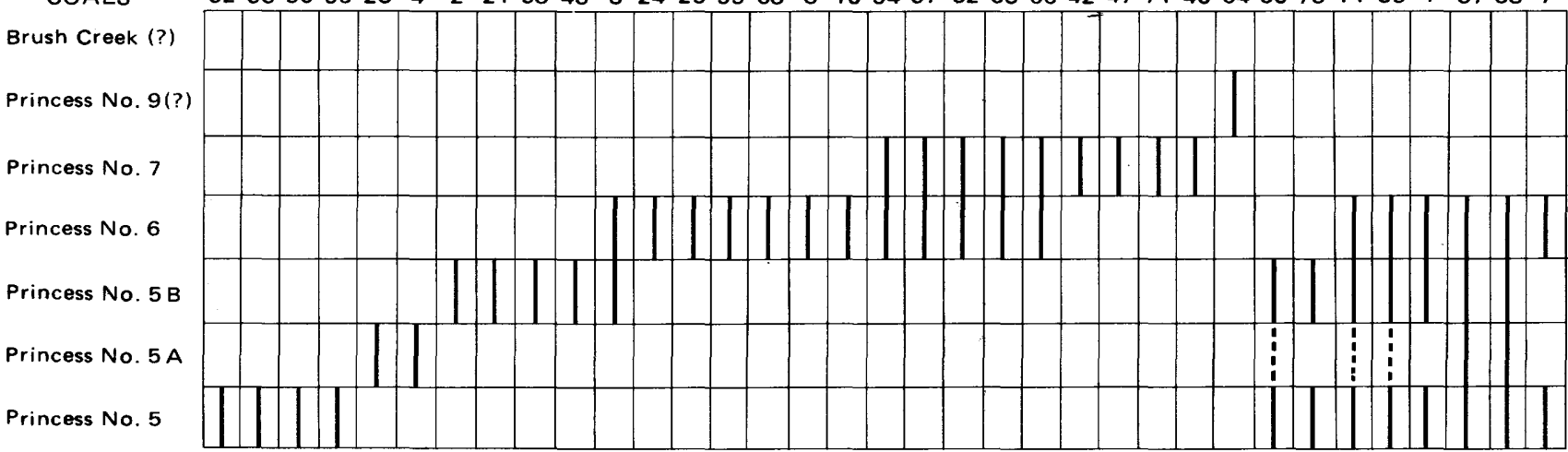

FIGURE 3. - The stratigraphic distribution of genera and species 
Princess No. 5 coal are plotted in figure 3. Zosterosporites triangularis is present in $238-\mathrm{Y}$ which is the roof rock of the coal. Savistrisporites nux is present in 238-AA which is a shale parting, whereas Reinschospora, Simozonotriletes, and Cristatisporites are all restricted to the seat-rock sample 238-CC.

The spore-pollen assemblage under consideration in this and younger coals contains several species of the genus Laevigatosporites which constitute a significant proportion of these assemblages. Four of these species are L. punctatus, L. globosus, L. minutus, and L. pseudothiessenii = Thymospora pseudothiessenii. Laevigatosporites punctatus (pl. 1, fig. 11) is thought to be conspecific with Torispora securis except for the unusual thickenings diagnostic of Torispora. A. H. V. Smith examined the individual photomicrographs of specimens shown in figures 10 and 12 of plate 1 , and he (written commun., Mar. 10, 1972) also considered them to be conspecific with Torispora securis. There is every reason to believe that Laevigatosporites punctatus is related to Torispora securis, but, for the reasons I have already expressed (Kosanke, 1969, p. 235), use of both binomials seems permissible. The specimens without this unusual thickening are classified as Laevigatosporites punctatus and constitute 8.1 percent of the assemblage of the coal samples. L. globosus and L. minutus (pl. 1, figs. 7,9 ) collectively occur as 4.6 percent of the total spore count in the coal samples. L. pseudothiessenii (pl. 1, fig. 8) has not been observed in either the Princess No. 5 or the Princess No. 5A coals. So far as is known the range zone of this species starts with the Princess No. 5B coal.

\section{PRINCESS NO. 5A COAL}

The No. 5A coal occurs between 292 feet $73 / 16$ inches and 294 feet $73 / 16$ inches in the Webbville 1 core hole and contains $14^{3} / 4$ inches coal and three shale partings. These shale partings have a total thickness of $4 \% / 8$ inches; some coal or shale, however, was lost in drilling. Figure $2 B$ graphically illustrates this interval and the prepared samples (macerations $238-\mathrm{P}-\mathrm{X}$ ). Both $238-\mathrm{P}$ and $\mathrm{Q}$ contained abundant fibrous opaque matter and poorly preserved
1. Ahrensisporites spp.
2. Alatisporites hexalatus
3. A. trialatus
4. A. sp.
5. Calamospora breviradiata
6. C. hartungiana
7. C. spp.
8. Cadiospora sp.
9. Cirratriradites annulatus
10. C. sp.

LIST OF TAXA SHC
granularis

20. Granulatisporites granularis
21. G. gibbosus

22. G. levis

23. G. pallidus

24. G. spinosus

25. G. verrucosus

26. $G$. spp.

27. Laevigatosporites desmoinensis

28. L. globosus

29. L. latus

30. L. medius

31. L. minutus

32. L. ovalis

33. L. pseudothiessenii

34. L. punctatus

35. L. vulgaris

36. Lycospora granulata

37. L. micropapillata

\section{WN IN DIAGRAM}

38. L. pseudoannulata

39. L. punctata

40. L. sp.

41. Murospora kosankei

42. Parasporites maccabei

43. Potonieisporites sp.

44. Punctatisporites obliquus

45. P. sulcatus

46. $P$. spp.

47. Raistrickia crinita

48. $R$. crocea

49. R. spp.

50. Reinschospora sp.

51. Reticulatisporites sp.

52. Savitrisporites nux

53. S. sp.

54. Schopfites dimorphus

55. S. sp.
56. Simozonotriletes sp.

57. Spackmanites ellipticus

58. Tantillus triquetrus

59. Torispora securis

60. Triquitrites additus

61. T. arculatus

62. T. exiguus

63. $T$. inusitatus

64. $T$. protensus

65. T. pulvinatus

66. T. spinosus

67. $T$. spp.

68. Vesicaspora wilsonii

69. Vestispora fenestrata

70. V. sp.

71. Wilsonites delicatus

72. $W$. spp.

73. Zosterosporites triangularis

TAXA

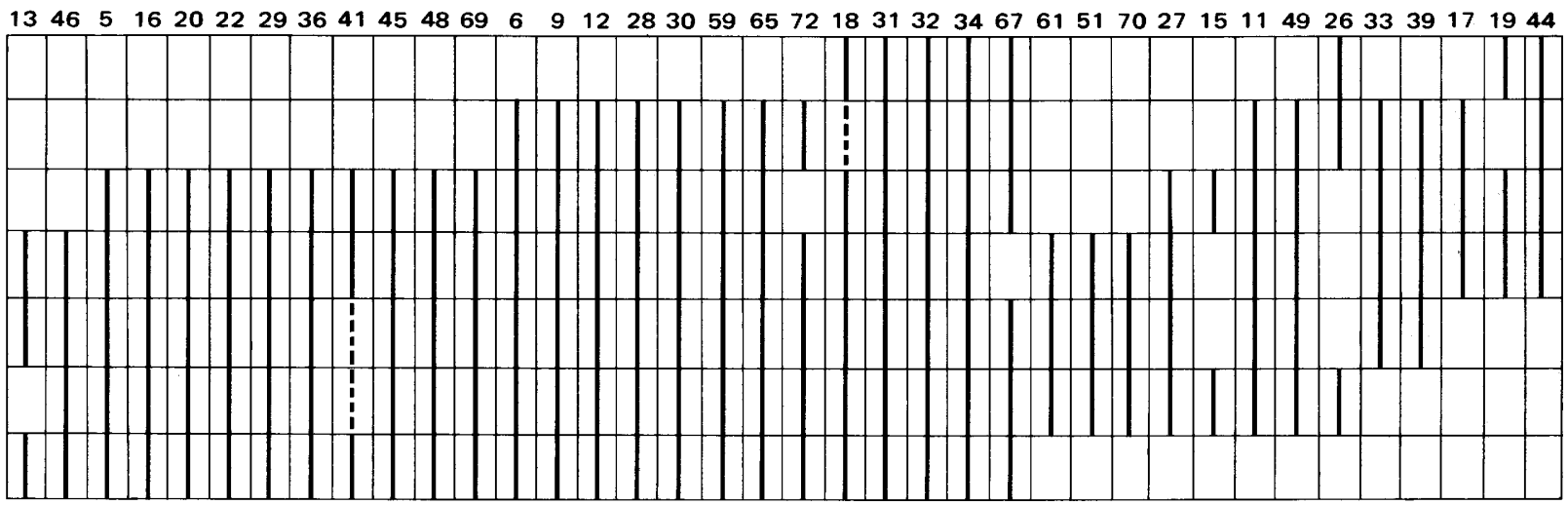

identified from the Princess No. 5 through the Brush Creek(?) coal. 
TABLE 2. - Percentage of genera of small spores in the Princess No. $5 \mathrm{~A}$ coal

At a depth of $292 \mathrm{ft}^{3} /{ }_{16}$ in. to $294 \mathrm{ft} 9^{11} / 1_{6}$ in., Webbville 1 core, on Little Cat Branch, about 1.4 miles west of Baker School, 24,200 ft FNL $\times 16,500 \mathrm{ft}$ FEL, Webbville quadrangle, Lawrence County, Ky. Paleobotanical loc. No. D4599-B. 1,250 specimens counted.
,+ present but not observed in statistical count or count not attempted]

\begin{tabular}{|c|c|c|c|c|c|c|c|c|c|}
\hline \multirow{2}{*}{$\begin{array}{l}\text { Genus } \\
\text { Maceration No. }\end{array}$} & \multicolumn{9}{|c|}{ Percent } \\
\hline & $238-P$ & $238-Q$ & $238-\mathrm{R}$ & $238-S$ & $238-\mathrm{T}$ & $238-U$ & $238-v$ & $238-w$ & $238-\mathrm{X}$ \\
\hline Alatisporites _-_-_-_ & ---- & ---- & + & ---- & ---- & ---- & ---- & ---- & ---- \\
\hline Calamospora & + & --- & 3.6 & ---- & 0.8 & 2.0 & 1.2 & 1.2 & + \\
\hline Cirratriradites __-_-_ & ---- & ---- & ---- & ---- & .4 & + & + & ---- & ---- \\
\hline Convolutispora _____ & ---- & $-\ldots-$ & ---- & $-\ldots-$ & ---- & ---- & 1.6 & + & ---- \\
\hline Crassispora _-_-_-- & + & ---- & ---- & ---- & .4 & .4 & .4 & 1.6 & ---- \\
\hline Densosporites___-__- & ---- & ---- & ---- & ---- & ---- & ---- & ---- & ---- & + \\
\hline Endosporites _-_---- & + & ---- & + & ---- & 1.6 & .4 & 22.4 & 15.6 & ---- \\
\hline Florinites & ---- & + & 1.2 & --- & .8 & .8 & .4 & + & ---- \\
\hline Granulatisporites _-_- & + & ---- & .8 & ---- & 2.4 & 1.2 & 2.4 & .4 & + \\
\hline Laevigatosporites _-_ & + & + & 4.4 & + & 14.4 & 27.6 & 8.0 & 24.4 & + \\
\hline Lycospora _.._-_-_- & + & + & 75.6 & ---- & 71.2 & 54.4 & 54.8 & 43.6 & + \\
\hline Punctatisporites _-_-_ & + & ---- & ---- & $-\ldots$ & .8 & ---- & 1.2 & + & + \\
\hline Raistrickia _____- & ---- & --- & + & ---- & + & .4 & .4 & .8 & ---- \\
\hline Reticulatisporites _-_- & ---- & $--\cdots$ & ---- & ---- & ---- & ---- & + & ---- & ---- \\
\hline Torispora & + & + & + & + & + & 2.8 & 1.2 & 4.4 & + \\
\hline Triquitrites _----_-- & + & + & 9.2 & + & 4.0 & 5.6 & 5.2 & 3.2 & + \\
\hline Vestispora & + & + & 1.6 & + & 2.0 & 2.4 & + & 2.8 & --- \\
\hline Wilsonites ________ & ---- & ---- & ---- & $-\ldots$ & ---- & + & .8 & --- & ---- \\
\hline Monosaccates _--_-- & --- & --- & 3.6 & + & 1.2 & 2.0 & ---- & 2.0 & ---- \\
\hline Total_------- & --- & $-\ldots$ & 100.0 & $-\ldots$ & 100.0 & 100.0 & 100.0 & 100.0 & ---- \\
\hline
\end{tabular}

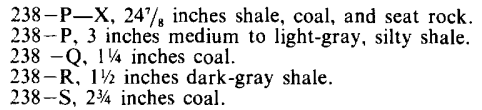

spores and pollen. Poor preservation was also noted in $238-\mathrm{S}$ and in the seat-rock sample 238-X. Although preservation was poor and abundance counts could not be made in 238-X, Torispora securis was seen to be fairly abundant.

The following genera are of numerical importance in the productive coal samples $(238-\mathrm{U}$ and $\mathrm{W})$ :

\begin{tabular}{|c|c|}
\hline Princess No. $5 \mathrm{~A}$ co & $\begin{array}{l}\text { Percent of } \\
\text { total count }\end{array}$ \\
\hline Lycospora _-_ & 45.9 \\
\hline Laevigatosporites & 22.4 \\
\hline Endosporites __-_-____-_- & 12.0 \\
\hline Triquitrites__--_-_--_--_-_- & 3.7 \\
\hline
\end{tabular}

Eighteen genera (table 2) have been identified from the samples of the Princess No. 5A coal and associated strata. A generic comparison of the 5A coal and the No. 5 coal (tables 1,2 ) reveals a close similarity in many respects. These similarities include 15 genera common to both sets of samples, and the generic differences that do exist concern generic abundance and genera that are not of numerical importance. Lycospora and Endosporites are more abundant in the No. 5A coal than in the No. 5 coal, and Torispora is much less abundant. The maximum abundance of Torispora
$238-T, 15$ inches light- to medium-gray shale.

$238-\mathrm{U}, 21 / 2$ inches coal.

$238-\mathrm{V}, 1 \frac{1 / 2}{2}$ inches medium-gray shale and vitrain

$238-\mathrm{W}, 81 \frac{1}{4}$ inches coal.
$238-\mathrm{X}, 2 \frac{1}{2}$ inches seat rock - dark-gray shale and vitrain.

in any single sample is only 4.4 percent. Associated with the drop in abundance of Torispora securis is a similar drop in abundance of Laevigatosporites punctatus. The relationship of these two species has already been discussed.

\section{PRINCESS NO. 5B COAL}

The coal between 281 feet $9 \%$ inches and 284 feet $3 \%$ inches in the Webbville 1 core hole is the Princess No. 5B coal. The roof shale of this sampled sequence contained abundant spores and pollen but so extremely thin and corroded that abundance counts were not made. The coal samples and seat rock yielded an excellent assemblage. The shale parting $13 / 4$ inches thick is shown diagrammatically in figure $2 C$; the sample from this parting $(238-\mathrm{M})$ yielded abundant but thin specimens for which a count was possible. The total coal thickness is $28 \frac{1}{2}$ inches; in this interval the following genera are numerically important:

\section{Princess No. $5 \mathrm{~B}$ coal}

\begin{tabular}{|c|c|}
\hline Genus & $\begin{array}{l}\text { Percent of } \\
\text { total count }\end{array}$ \\
\hline Laevigatosporites___-_-_-_-_-_ & 46.8 \\
\hline Lycospora & 32.9 \\
\hline Endosporites _-_-_--_-_--_- & 5.5 \\
\hline Densosporites _-_-_-_-_-_-_ & 3.4 \\
\hline Triquitrites & 3.0 \\
\hline Total & 91.6 \\
\hline
\end{tabular}




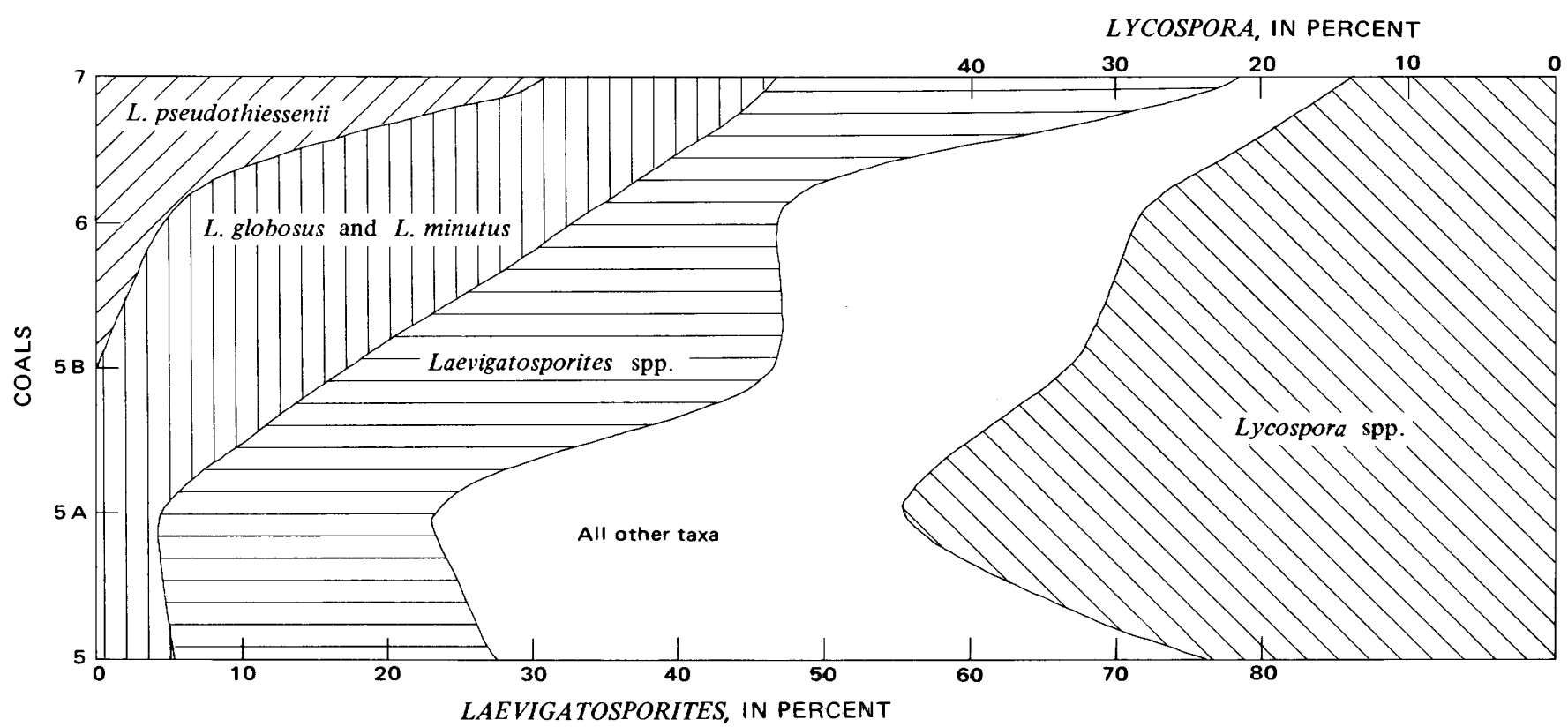

Figure 4. - Abundance of selected genera and species observed in the Princess Nos. 5-7 coals from the Princess reserve district of northeastern Kentucky. Abundance of Laevigatosporites increases from the Princess No. 5 through the Princess No. 7 coal largely as the result of the increase of $L$. pseudothiessenii. More than 90 percent of the assemblage of the Princess No. 7 coal belongs to either Laevigatosporites or Lycospora.

Seven species of Laevigatosporites occur in both the Princess Nos. 5A and 5B coals, and the species are much more abundant in the $5 \mathrm{~B}$ coal, as shown in figure 4. $L$. globosus and L. minutus account for 16.4 percent of the spore-pollen assemblage of the coal samples $(238-\mathrm{K}, \mathrm{L}, \mathrm{N})$, is contrasted to only 3.8 percent of the assemblage of the $5 \mathrm{~A}$ coal. These two species continue to increase in both the Princess No. 6 and the Princess No. 7 coals. L. pseudothiessenii is present in the seat-rock samples of the 5B coal $(238-\mathrm{O})$ and may be represented in the coal samples by several poor specimens that were not identified to the specific level. The range zone of $L$. pseudothiessenii is from the Princess No. 5B coal through the Princess No. 9(?) coal which is represented by maceration series 163 . This would be a range zone of less than 200 feet in the northern part of the Princess reserve district to slightly more than 200 feet in the southern part of the district. A complete list of identified species is shown in figure 3.

Twenty-three genera (table 3 ) have been identified from the 5B coal. Zosterosporites triangularis, Potonieisporites sp., and Tantillus triquetrus have been observed only in the seat-rock sample (238-0). Both Alatisporites trialatus and $A$. hexalatus are present, and this is not unexpected at this stratigraphic position of the Princess No. 6 coal should be correlative with the Illinois Colchester (No. 2) coal. Torispora securis occurs at the rate of 11 percent in the seatrock sample and averages less than 1 percent in the coal samples.
PRINCESS NO. 6 COAL

The coal at 226 feet 5 inches to 229 feet 5 inches in the Webbville 1 core hole is considered to be the Princess No. 6 coal. A diagrammatic log is shown in figure $2 F$. The top sample, $238-\mathrm{E}$, is a mixture of black shale, a thin coal layer, and mottled gray shale. The main coal sample, $238-\mathrm{F}-\mathrm{H}$, is without major partings as contrasted to a second sample collected from the south side of Interstate 64 in Rush quadrangle $(3,600 \mathrm{ft} F E L \times 2,900 \mathrm{ft} \mathrm{FNL})$, Boyd County, Ky. This set of samples is maceration series $161-\mathrm{A}-\mathrm{I}$, and a diagrammatic $\log$ is shown in figure $2 E$. It is apparent that coal deposition was interrupted twice. All samples $(238-E-I)$ from the diamond-drill hole yielded abundant spores; pollen and generic occurrence and abundance are reported in table 4 . The outcrop samples of the Princess No. 6 coal $(161-\mathrm{A}-\mathrm{I})$ yielded abundant spores and polen grains, except for the two noncoal samples $(161-C, D)$. Generic occurrence and abundance are presented in table 5.

The samples of the Princess No. 6 coal examined contained partings and this feature is present in a sample of the Lower Kittanning coal from Lawrence County, Ohio, as reported by Gray (1967). The rest of Gray's samples from the Lower Kittanning coal did not possess shale partings, and Habib (1966) did not indicate the presence of partings in the 15 samples of the Lower Kittanning coal he examined from Pennsylvania.

The numerically important genera from the two samples of the Princess No. 6 coal examined are as follows: 
Princess No. 6 coal

\begin{tabular}{|c|c|c|c|}
\hline \multirow[b]{2}{*}{ Genus } & \multicolumn{3}{|c|}{ Percent of total count } \\
\hline & $238-\mathrm{F}-\mathrm{H}$ & $161-A-I$ & Composite \\
\hline Calamospora & 2.2 & 2.0 & 2.1 \\
\hline 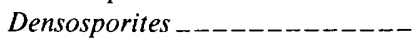 & 7.2 & 1.1 & 4.1 \\
\hline Endosporites _------- & 1.8 & 3.9 & 2.8 \\
\hline Florinites _--_-- & 3.3 & (') & 1.6 \\
\hline Laevigatosporites & 52.8 & 39.2 & 46.0 \\
\hline Lycospora & 20.8 & 38.2 & 29.5 \\
\hline Punctatisporites _----------- & 1.0 & 1.6 & 1.3 \\
\hline Triquitrites -------------- & 2.6 & 4.7 & 3.6 \\
\hline Total__- & 91.7 & 90.7 & 91.0 \\
\hline
\end{tabular}

(1) Less than 1 percent.

TABLE 3. - Percentage of genera of small spores in the Princess No. $5 B$ coal

[At a depth of $281 \mathrm{ft} 65 \%$ in. to $284 \mathrm{ft} 6 \%$ in., Webbville 1 core on Little Cat Branch about 1.4 miles west of Baker School, 24,000 ft FNL $\times 16,500 \mathrm{ft} \mathrm{FEL}$, Webbville quadrangel, Lawrence County Ky. Paleobotanical loc. No. D4599-C. 1,250 specimens counted. +, present but not observed ir statistical count, or no count attempted

\begin{tabular}{|c|c|c|c|c|c|c|}
\hline \multirow{2}{*}{$\begin{array}{l}\text { Genus } \\
\text { Maceration No. }\end{array}$} & \multicolumn{6}{|c|}{ Percent } \\
\hline & $238-\mathrm{J}$ & $238-\mathrm{K}$ & $238-\mathrm{L}$ & $.238-\mathrm{M}$ & $238-\mathrm{N}$ & $238-\boldsymbol{C}$ \\
\hline Ahrensisporites _ & $-\ldots$ & ---- & + & -- & + & 1.2 \\
\hline Alatisporites _- & ---- & $\ldots \ldots$ & $\ldots \ldots$ & + & 0.4 & ---- \\
\hline Calamospora _- & + & 3.6 & 0.8 & 0.8 & .8 & .4 \\
\hline Cirratriradites - & $\ldots-\ldots$ & + & ---- & ---- & .8 & + \\
\hline Convolutispora & + & $-\ldots$ & ---- & ---- & + & ---- \\
\hline Crassispora _-- & + & --- & .4 & ---- & + & ---- \\
\hline Cristatisporites(?) & $\ldots$ & ---- & ---- & --- & .4 & --- \\
\hline Densosporites _- & + & ---- & ---- & + & 8.4 & .8 \\
\hline Endosporites -- & + & 7.6 & 5.2 & $\ldots$ & 4.0 & + \\
\hline Florinites _-_-- & --- & + & .4 & 5.2 & .4 & 1.2 \\
\hline Granulatisporites & -- & 3.2 & .8 & 1.6 & 3.6 & 16.4 \\
\hline Laevigatosporites & + & 52.4 & 30.0 & 72.0 & 37.2 & 36.4 \\
\hline Lycospora & + & 22.8 & 42.8 & 5.2 & 33.2 & 6.8 \\
\hline Potonieisporites & $\ldots \ldots$ & $\ldots \ldots$ & $\ldots$ & $\ldots \ldots$ & --- & + \\
\hline Punctatisporites & --- & 1.6 & 3.2 & 1.6 & 2.4 & 1.6 \\
\hline Raistrickia --- & + & + & + & + & - - & + \\
\hline Reticulatisporites & ---- & ---- & ---- & $\ldots-\ldots$ & .4 & .4 \\
\hline Tantillus __-_- & ---- & ---- & -- & ---- & $\ldots$ & + \\
\hline Torispora _... & ---- & .8 & .4 & .4 & 1.2 & 11.2 \\
\hline Triquitrites _--- & + & 4.8 & 1.2 & 1.2 & 3.2 & 14.0 \\
\hline Vestisporc _--_ & + & + & 12.0 & - & .4 & .8 \\
\hline Wilsonites_-_-_ & $-\ldots$ & + & .8 & 2.0 & ---- & 2.4 \\
\hline Zosterosporites_ & ---- & ---- & $\ldots$ & ---- & ---- & 3.2 \\
\hline Monosaccates _- & ---- & 3.2 & 2.0 & 10.0 & 3.2 & 3.2 \\
\hline All other taxa _- & ---- & ---- & + & ---- & $--\cdots$ & + \\
\hline Total _--- & ---- & 100.0 & 100.0 & 100.0 & 100.0 & 100.0 \\
\hline
\end{tabular}

DESCRIPTION OF MATERIALS IN MACERATIONS

$238-\mathrm{J}-\mathrm{O}, 36 \frac{1 / 4}{4}$ inches shale, coal, and seat rock.

$238-\mathrm{J}, 3$ inches hard finely micaceous shale and $1 / 2$ inch vitrain.

$238-\mathrm{K}, 9$ inches coal.

$238-\mathrm{L}, 9$ inches coal.

$238-\mathrm{N}, 10 \% / 4$ inches coal.

$238-0,31 / 4$ inches seat rock - dark-gray to black clay.
TABLE 4. - Percentage of genera of small spores in the Princess No. 6 coal

[At a depth of $226 \mathrm{ft} 7 / 8$ in. to $229 \mathrm{ft} 8 \mathrm{in}$., Webbvile 1 core, on Little Cat Branch about 1.4 miles west of Baker School, 24,000 ft FNL $\times 16,500 \mathrm{ft}$ FEL, Webbville quadrangle, Lawrence County, Ky. Paleobotanical loc. No. D4599-D. 1,500 specimens counted. +, present but not observed in

\begin{tabular}{|c|c|c|c|c|c|c|}
\hline \multirow{2}{*}{$\begin{array}{l}\text { Genus } \\
\text { Maceration No. - }\end{array}$} & \multicolumn{6}{|c|}{ Percent } \\
\hline & $238-\mathrm{E}$ & $238-F$ & $238-G$ & $238-\mathrm{H}$ & $238-\mathbf{H}^{1}$ & $238-I$ \\
\hline Ahrensisporites__ & ---- & --- & ---- & --- & ---- & + \\
\hline Calamospora _- & + & 0.8 & 1.6 & 4.4 & 6.4 & 3.6 \\
\hline Cirratriradites - & ---- & .4 & .8 & 2.8 & 1.2 & .4 \\
\hline Convolutispora _ & ---- & ---- & ---- & + & ---- & + \\
\hline Crassispora --- & --- & ---- & ---- & --- & ---- & .4 \\
\hline Densosporites _- & 6.8 & 16.8 & ---- & 4.8 & ---- & ---- \\
\hline Endosporites _- & $-\ldots-$ & ---- & ---- & 5.6 & .8 & .4 \\
\hline Florinites _---- & .4 & + & 8.4 & 1.6 & 1.2 & 2.0 \\
\hline Granulatisporites & 3.2 & .8 & .4 & .8 & 2.8 & 4.8 \\
\hline Laevigatosporites & 72.4 & 64.0 & 56.8 & 37.6 & 17.6 & 20.8 \\
\hline Lycospora & 11.2 & 7.6 & 24.8 & 30.0 & 60.4 & 47.2 \\
\hline Murospora _._- & .4 & ---- & ---- & .4 & ---- & $-\cdots$ \\
\hline Punctatisporites & .4 & 1.6 & .8 & .8 & .4 & .8 \\
\hline Raistrickia _-_- & + & .8 & + & .8 & .4 & .8 \\
\hline Schopfites _-_- & 1.6 & 1.6 & 2.8 & .4 & ---- & --- \\
\hline Spackmanites_-- & ---- & ---- & ---- & + & --- & ---- \\
\hline Torispora _--- & ---- & --- & ---- & ---- & ---- & .4 \\
\hline Triquitrites _-_- & 2.0 & 2.4 & .8 & 4.8 & 5.2 & 6.4 \\
\hline Vestispora _-_- & + & ---- & ---- & .8 & 3.2 & .8 \\
\hline Wilsonites _-_-- & ---- & ---- & + & ---- & ---- & 3.2 \\
\hline Monosaccates - & .8 & 3.2 & 2.8 & 4.4 & .4 & 7.6 \\
\hline All other taxa & .8 & ---- & + & ---- & ---- & .4 \\
\hline Total _-_ & 100.0 & 100.0 & 100.0 & 100.0 & 100.0 & 100.0 \\
\hline \multicolumn{7}{|c|}{ 'A very thin shale parting less than $1 / 8$ inch thick. } \\
\hline \multicolumn{7}{|c|}{ DESCRIPTION OF MATERIAL IN MACERATIONS } \\
\hline $\begin{array}{l}238-\mathrm{E}-\mathrm{I}, 431 / \mathrm{s} \text { inches } \\
238-\mathrm{E}, 41 / 8 \text { inches blac } \\
238-\mathrm{F}, 12 \text { inches coal. } \\
238-\mathrm{G}, 12 \text { inches coal. } \\
238-\mathrm{H}, 12 \text { inches coal. } \\
238-\mathrm{I}, 3 \text { inches seat ro }\end{array}$ & $\begin{array}{l}\text { ale, coal, } \\
\text { mottled }\end{array}$ & $\begin{array}{l}d \text { seat rocl } \\
\text { y shale anc }\end{array}$ & coal. & & & \\
\hline
\end{tabular}

The same genera and species, with minor exceptions, are present in both sets of samples. The primary difference is in the abundance of numerically significant genera. Such differences can be attributed to differences in thickness of samples being compared, differences in environmental conditions at the time of deposition, or both.

Taxa identified from the Princess No. 6 coal samples (238-E-I and 161-A-I) are shown in figure 3. There are numerous ranges that appear to originate in, to terminate in, or to be confined to, the Princess No. 6 coal, as shown. Additional information will be required to more accurately assess the authenticity of these range zones. Schopfites is present in the Princess No. 6 coal, and, so far as is known, this occurrence is the start of the range zone of this genus in the Appalachians. I did not observe this genus in either the Princess 5A or the Princess 5B coals below the Vanport Limestone Member of the Breathitt Formation, 
TABLE 5. - Percentage of genera of small spores in the Princess No. 6 coal

[From a roadcut on the south side of Interstate 64, 3,600 ft FEL $\times 3,200 \mathrm{ft} \mathrm{FNL,} \mathrm{Rush} \mathrm{quadrangle,} \mathrm{Boyd} \mathrm{County,} \mathrm{Ky.} \mathrm{Paleobotanical}$ loc. No. D4600. 1,500 specimens counted. + , present but not observed in statistical count, or count not attempted]

\begin{tabular}{|c|c|c|c|c|c|c|c|c|}
\hline \multirow{2}{*}{$\begin{array}{l}\text { Genus } \\
\text { Maceration No. }\end{array}$} & \multicolumn{8}{|c|}{ Percent } \\
\hline & $161-A$ & $161-B$ & $161-C$ & $161-D$ & $161-E$ & $161-F$ & $16 i-H$ & $161-I$ \\
\hline Ahrensisporites__-_- & ---- & ---- & ---- & ---- & ---- & ---- & ---- & + \\
\hline Alatisporites ------ & ---- & ---- & --- & ---- & ---- & ---- & + & + \\
\hline Calamospora & 6.8 & 2.0 & + & ---- & 0.4 & 0.8 & 0.4 & 0.8 \\
\hline Cadiospora & ---- & ---- & + & ---- & ---- & ---- & ---- & ---- \\
\hline Cirratriradites & 2.0 & .4 & + & ---- & .4 & .4 & + & ---- \\
\hline Convolutispora & ---- & .8 & + & $--\cdots$ & 1.6 & --- & ---- & + \\
\hline Crassispora _...... & 1.2 & --- & ---- & ---- & ---- & ---- & --- & + \\
\hline Cristatisporites _----- & ---- & ---- & ---- & ---- & ---- & ---- & + & ---- \\
\hline Densosporites____-_ & --- & ---- & $-\cdots-$ & ---- & ---- & ---- & 4.4 & + \\
\hline Endosporites _----- & 6.0 & 10.8 & + & --- & 7.2 & .8 & + & 1.6 \\
\hline Florinites -------- & + & --- & + & + & --- & ---- & + & + \\
\hline Granulatisporites _--- & 2.8 & 4.0 & --- & $-\cdots-$ & 1.2 & .4 & .4 & 3.6 \\
\hline Laevigatosporites --- & 34.4 & 28.8 & + & + & 25.6 & 71.6 & 20.0 & 65.6 \\
\hline Lycospora _--_---- & 26.4 & 31.2 & + & + & 52.4 & 10.8 & 71.6 & 23.6 \\
\hline Punctatisporites _---- & 2.0 & 2.4 & ---- & ---- & 4.0 & 1.6 & 1.2 & 1.2 \\
\hline Raistrickia _------- & ---- & .8 & + & ---- & .4 & 2.8 & .4 & + \\
\hline Reticulatisporites _--- & ---- & ---- & ---- & ---- & ---- & ---- & ---- & + \\
\hline Schopfites _------- & .8 & 2.0 & ---- & $(?)$ & ---- & $.4(?)$ & ---- & ---- \\
\hline Spackmanites ___ _- & ---- & + & ---- & ---- & ---- & ---- & ---- & $---\frac{-}{8}$ \\
\hline Torispora & ---- & --- & ---- & ---- & ---- & ---- & ---- & .8 \\
\hline Triquitrites _----- & 9.6 & 8.4 & + & + & 1.2 & 9.6 & .4 & .8 \\
\hline Vesicaspora _-_- & .4 & ---- & ---- & $-\cdots$ & + & ---- & ---- & ---- \\
\hline Vestispora & 3.2 & .8 & $-\cdots$ & ---- & .4 & ---- & + & + \\
\hline Wilsonites _- ------ & --- & ---- & + & ---- & .8 & ---- & .8 & .8 \\
\hline Monosaccates_-_--- & 4.4 & 7.6 & ---- & ---- & 4.4 & .8 & .4 & 1.2 \\
\hline All other taxa & ---- & ---- & ---- & --- & ---- & ---- & + & + \\
\hline Total ------- & 100.0 & 100.0 & --- & ---- & 100.0 & 100.0 & 100.0 & 100.0 \\
\hline
\end{tabular}

DESCRIPTIONS OF MATERIALS IN MACERATIONS

$161-A-1,67^{3 / 4}$ inches roof rock - coal, clay-shale-siltstone partings, and seat rock. $161-A, 9 \frac{1}{2}$ inches coal.

$161-\mathrm{B}, 91 / 2$ inches coal.

$161-C, 11$ inches medium- to dark-gray shale, transitional to 53 -inch clay unit with ironstone concretions in lower half of unit

$161-D, 5$ inches medium-gray carbonaceous clay.

and Gray (1967) did not report the genus from the Lawrence coal of Ohio which occurs above the Vanport Limestone Member and below the Lower Kittanning coal. Spackmanites ellipticus was described from the Lower Kittanning coal of Pennsylvania by Habib (1966). Gray (1967) reported the presence of some spore types that he did not name, and three of these are most assuredly congeneric with Spackmanites. Gray's report probably was in press before Habib's was published. In any event, from Gray's publication it is obvious that Spackmanites was observed from the Lawrence through the Middle Kittanning coal. I have observed $S$. ellipticus in both the Princess No. 6 and the Princess No. 7 coals but not in the Princess No. 5, 5A, or 5B coals, although a few specimens assignable to this genus have been observed as low as the Francis coal from eastern Kentucky. Peppers (1970) reported Spackmanites present in
$161-F, 5 \frac{1}{4}$ inch unit black shale; 1 inch gray clay $23 / 4$ inch black semiflint.

$161-G, 1$ inch gray, very micaceous, carbonaceous, badly weathered siltstone. This unit was barren of spores and pollen.

$61-\mathrm{H}, 13$ inches coal.

$161-1,10$ inches coal with 1 inch bone at top.

161-J, 1 inch seat rock, ganisterlike, iron stain, barren of spores and pollen.

the Colchester (No. 2) coal of Illinois through the Herrin (No. 6) coal of Illinois. The genus has not been reported as occurring abundantly, but it is readily recognized and, as such, may prove of value for correlation purposes.

The range zone of Densosporites triangularis terminates with the Princess No. 6 coal, although two specimens assignable to Densosporites have been observed in the Princess No. 7 coal. Gray (1967) indicated this species present in the Lower Kittanning coal of Ohio and Pennsylvania but absent from the Strasburg and Middle Kittanning coals above; he found two specimens assignable to Densosporites in the Middle Kittanning coal. Peppers (1970) recorded $D$. triangularis from the Colchester (No. 2) coal and possibly as high as the next coal above, the Lowell coal, which he reported as the termination of the generic range zone.

Laevigatosporites pseudothiessenii is consistently present, 
ranging from 1 to 6 percent of the spore population. $L$. punctatus represents less than 2 percent of the spore population, but $L$. globosus and L. minutus combined represent 26-40 percent of the total assemblage.

\section{PRINCESS NO. 7 COAL}

The coal at 190 feet $53 / 4$ inches to 192 feet $23 / 4$ inches in the Webbville 1 core hole is the Princess No. 7 coal. A diagrammatic $\log$ of the coal is shown in figure $2 G$. The coal is 21 inches thick and has a shale roof and a clay seat rock. A second sample was collected from the south side of Interstate 64 in Rush quadrangle (1,800 ft FEL $\times 2,900 \mathrm{ft}$ FNL), Boyd County, Ky. The set of samples is maceration series $160-\mathrm{A}-\mathrm{G}$; a diagrammatic $\log$ is shown in figure $2 D$. The main part of the coal is 45 inches thick with a 2 -inch clay parting separating it from the top $3 \frac{3}{4}$ inches of coal. All samples from the diamond-drill core $(238-\mathrm{A}-\mathrm{D})$ yielded abundant spores and pollen grains; generic occurrence and abundance are reported in table 6 . The outcrop samples of the Princess No. 7 coal $(160-A-G)$ yielded abundant spores and pollen grains in all coal samples and the seat rock. The roof shale (160-A) and the clay parting (160-C) did not yield either abundant or well-preserved spores or pollen grains. Generic occurrence and abundance are reported in table 7 .

The numerically important genera from the two samples of the Princess No. 7 coal are as follows:

Princess No. 7 coal

\begin{tabular}{lrrrr}
\hline & \multicolumn{3}{c}{ Percent of total count } \\
\cline { 2 - 5 } Genus & $238-\mathrm{B}, \mathrm{C}$ & $160-\mathrm{B}, \mathrm{D}-\mathrm{G}$ & Composite \\
\hline Laevigatosporites & 81.8 & 77.6 & 79.7 \\
Lycospora ---1.8 & 13.0 & 13.6 \\
Punctatisporites & 14.2 & 4.1 & 2.4 \\
Triquitrites & .8 & 2.1 & 1.9 \\
\multicolumn{1}{c}{ Total } & 1.8 & 96.8 & 97.6 \\
\hline
\end{tabular}

The correspondence between the two sets of samples is considered to be very close despite the great differences between the two in thickness and partings. Laevigatosporites is clearly dominant in the Princess No. 7 coal, inasmuch as the genus represents more than 75 percent of the total population. This is a significant increase in the abundance of Laevigatosporites because the genus represents less than half of the population of the Princess No. 6 coal. Laevigatosporites and Lycospora together are more than 90 percent of the spore-pollen assemblage of the Princess No. 7 coal. This content is illustrated in figure 4, and it is also possible from this illustration to see that the cause for this increase in abundance of Laevigatosporites is partly the increase in L. pseudothiessenii.

Twenty genera are present in the Princess No. 7 coal (tables 6,7), and 15 of these genera are common to both the 238 and 160 maceration series. So far as is known, the range zones of Schopfites, Densosporites, and Murospora terminate with the Princess No. 7 coal. I have observed Densosporites from younger rocks elsewhere in the United States, but these occurrences have always been from noncoal samples. Although other differences between the Princess No. 7 and younger coals can be cited, it seems wise to defer such action pending additional information. A complete list of all species identified from the Princess No. 7 coal is shown in figure 3 .

\section{PRINCESS NO. 8(?) COAL}

Three samples were collected about 30 feet above the Princess No. 7 coal in a roadcut on the south side of Interstate 64, 1,200 feet FEL $\times$ 2,700 feet FNL, Rush quadrangle, Boyd County, Ky. These samples were completely barren of identifiable spores or pollen grains. No coal is present at this locality, but a black shale 3 inches thick and somewhat transitional to bone coal is present above a ganisterlike seat rock, which has a clay roof.

\section{PRINCESS NO. 9(?) COAL}

Nine samples of this coal were collected about 30 feet above the previous sample in a roadcut on the south side of Interstate 64, 1,100 feet FEL $\times$ 2,700 feet FNL, Rush quadrangle, Boyd County, Ky. These samples represent a series of shale, coal, clay, coal, and seat rock and have been assigned maceration numbers $163-\mathrm{A}-\mathrm{I}$. All these samples were weathered; nevertheless, representatives of 13 genera were identified. Taxa identified are shown in figure 3 . Inasmuch as Lycospora is present, we are still within the range zone of this genus. Torispora securis, Laevigatosporites punctatus, and L. pseudothiessenii are also taxa of this assemblage.

\section{BRUSH CREEK(?) COAL}

A coal near the top of the roadcut on the south side of Interstate 64, 1,000 feet FEL $\times 2,750$ feet FNL, Rush quadrangle, Boyd County, Ky., is thought to be the Brush Creek coal. Unfortunately, the entire $16 \frac{1 / 2}{2}$ inches of coal was very badly weathered as were the seat-rock and roof samples. Pollen and spore recovery and preservation are very poor. Taxa identified are shown in figure 3 .

Because recovery and preservation are poor, some doubt exists as to whether Lycospora, Laevigatosporites pseudothiessenii, and Torispora securis are absent because of their lack of preservation or because the samples were taken above the range zone of these taxa. If the samples are, in fact, that of the Brush Creek coal, as suspected, we would be above the range zones of these taxa.

\section{ZOSTEROSPORITES, n. gen.}

Type species. - Zosterosporites triangularis, $\mathrm{n}$. $\mathrm{sp}$.

Diagnosis. - Spores radial, trilete with rays long, more than three-fourths the distance to the spore margin, fairly straight, and lips narrow but distinct. Aperture often torn 
TABLE 6. - Percentage of genera of small spores in the Princess No. 7 coal [At a depth of $190 \mathrm{ft} 0$ in. to $192 \mathrm{ft} 61 / 4$ in., Webbville 1 core, on Little Cat Branch about 1.4 miles west of Baker School, 24,200 ft FNL $\times 16,500 \mathrm{ft}$ FEL, Webbville quadrangle, Lawrence County, Ky. Paleobotanical loc. No. D4599-E. 1,000 specimens counted. +, present but not observed in
statistical count]

\begin{tabular}{llllll}
\hline Genus & \multicolumn{5}{c}{ Percent } \\
\cline { 2 - 5 } Maceration No. & & & & \\
\hline
\end{tabular}

\begin{tabular}{|c|c|c|c|c|}
\hline Calamospora _- & 2.0 & + & 1.6 & 0.4 \\
\hline Cirratriradites_- & + & + & + & 2.0 \\
\hline Crassispora _-_ & ---- & + & + & 1.2 \\
\hline Densosporites _- & .8 & --- & ---- & (?) \\
\hline Endosporites _- & ---- & ---- & ---- & 1.2 \\
\hline Florinites _-_-_ & $-\ldots--$ & $-\ldots-\ldots$ & + & .4 \\
\hline Granulatisporites & 1.6 & 0.4 & .4 & 6.0 \\
\hline Laevigatorsporites & 75.6 & 94.4 & 69.2 & 23.2 \\
\hline Lycospora _-_- & .8 & 1.2 & 27.2 & 26.8 \\
\hline Murospora _-- & ---- & ---- & $-\cdots-$ & + \\
\hline Punctatisporites & 3.2 & 1.2 & .4 & 20.0 \\
\hline Raistrickia ___- & .4 & + & + & .8 \\
\hline Schopfites _-__ & .4 & + & + & ---- \\
\hline Spackmanites __ & $-\ldots-$ & ---- & ---- & 2.0 \\
\hline Torispora _--- & 14.4 & + & + & 8.8 \\
\hline Triquitrites _-- & .8 & 2.4 & 1.2 & ---- \\
\hline Vestispora & ---- & ---- & ---- & + \\
\hline Wilsonites _--- & ---- & --- & ---- & + \\
\hline Monosaccates _- & ---- & .4 & ---- & 5.2 \\
\hline All other taxa -- & ---- & ---- & ---- & 2.0 \\
\hline Total _-- & 100.0 & 100.0 & 100.0 & 100.0 \\
\hline
\end{tabular}

DESCRIPTION OF MATERIAL IN MACERATIONS

$238-\mathrm{A}-\mathrm{D}, 30 \frac{1 / 4}{4}$ inches shale, coal, and seat rock

$238-\mathrm{A}, 5^{3 / 4}$ inches shale, black and gray-green slickensided units. $238-\mathrm{B}, 10 \frac{1 / 2}{2}$ inches coal.

$238-\mathrm{C}, 10 \frac{1 / 2}{2}$ inches coal.

$238-\mathrm{D}, 3 \frac{1}{2}$ inches seat rock - medium-gray fractured slip clay.

open leaving triangular opening of the proximal surface. Outline in proximo-distal view triangular with interradial margins smooth or slightly crenulate and overall concave, straight, or slightly convex. In longitudinal section spores flattened elliptical. The spore coat is levigate, thin, light yellow except for a thickened belt or band at or near the equator which encircles the body forming the rounded bulbous corners. Beltlike thickening a darker color and $3 \mu$ to $5 \mu$ (microns) thick. Folding of body wall adjacent to belt common. Overall size small, ranging from $25 \mu$ to $34 \mu$ based on measurements of 29 specimens from one slide.

Etymology. - The name is selected because of the beltlike thickening ( $\mathrm{Gr}$. zoster, belt or girdle).

Zosterosporites triangularis, n. sp.

Diagnosis. - Monotypic, same as for genus.

Etymology. - Reference is made to typical triangular outline in proximo-distal view.

Affinity. - Unknown, but general morphology is similar to that found among some ferns.

Discussion. - There are two obvious comparisons that
TABLE 7. - Percentage of genera of small spores in the Princess No. 7 coal

[From a roadcut on the south side of Interstate $64,1,800 \mathrm{ft} \mathrm{FEL} \times 2,900 \mathrm{ft}$ FNL, Rush quadrangle, Boyd County, Ky. Paleobotanical loc. No. D4601. 1,250 specimens counted. +, present but no observed in statistical count, or count not attempted.]

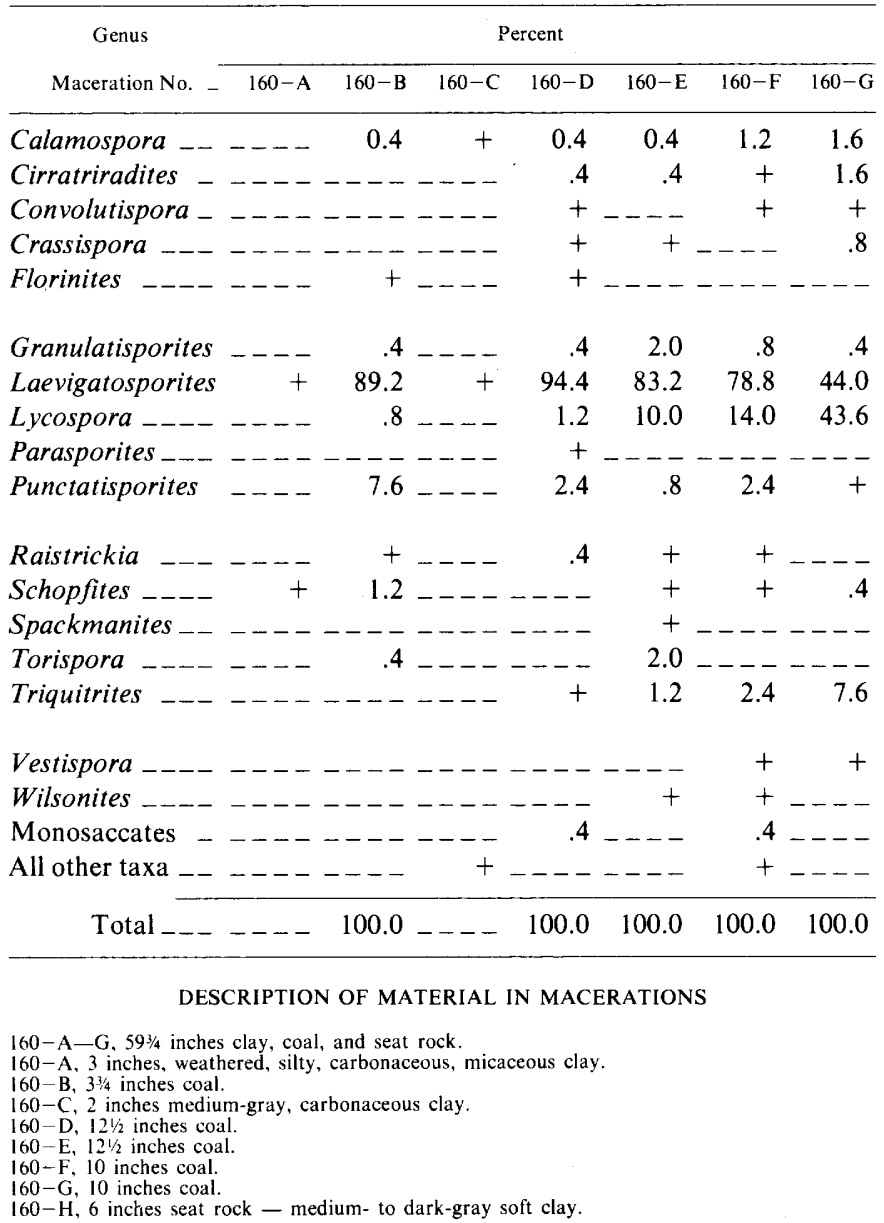

should be made. One is with Triquitrites because of the small size, the shape, and the bulbous corners. However, these bulbous corners are not analogous to the arcuate thickenings so characteristic of species of Triquitrites (fig. 5). The beltlike thickening at or near the equator is somewhat similar to the spore coat of Savitrisporites.

Occurrence. - Zosterosporites triangularis has been observed in the roof rock of the Princess No. 5 coal, the seat rock of the Princess No. 5B coal, the Richardson coal, and the Skyline coal of eastern Kentucky. These occurrences are all within the Breathitt Formation of Kentucky.

Holotype. - Plate 1, figures 1, 2, Princess No. 5B coal, USGS Paleobotanical locality D4599-C, maceration series $238-\mathrm{O}$, single-grain mount $1,108.9 \times 14.5$. Negative numbers are 1969 for figure 1 and 1792 for figure 2 .

Paratypes. - All from USGS Paleobotanical locality D4599-C and maceration series 238-O. Figure 3, slide 2, $103.1 \times 11$, and negative number 1752 . Figure 4 , slide 5 , 109.7 $\times 7.7$, and negative number 1973. Figure 5, slide 3, $111.9 \times 12.0$, and negative number 1771. Figure 6, slide 5, $109.4 \times 8.3$, and negative number 1793 . 


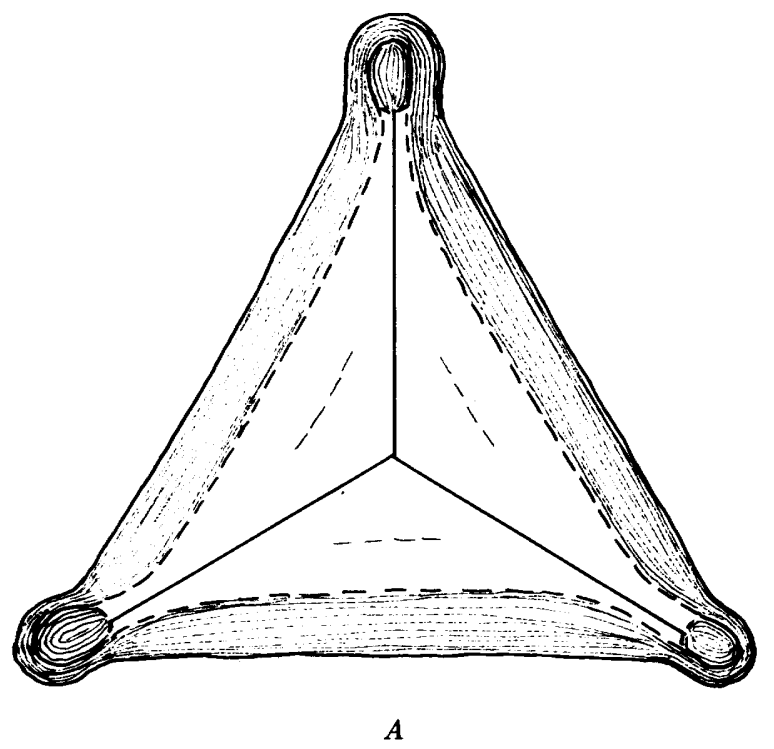

FIGURE 5. - Diagrammatic drawings of Zosterosporites triangularis, n. gen., n. sp. $A$, Proximal view; $B$, longitudinal section; $C$, distal view. Not to scale.

Repository. - All type specimens are preserved in the paleobotanical collections of the U.S. Geological Survey, Denver, Colo.

\section{CORRELATION OF THE PRINCESS COALS}

The Princess No. 5 coal has been correlated by Huddle, Lyons, and Ferm (1963, p. 28) with the Richardson coal of the Licking River and Big Sandy reserve districts and with the Skyline coal of the Hazard reserve district. Palynological comparisons of the available samples of the Princess No. 5, Richardson, and Skyline coals are difficult because total coal thickness varies from $93 / 8$ inches in the Princess No. 5 coal to more than 170 inches in the Skyline coal. Further, important changes in assemblage composition occur in the thick Skyline coal that are only partly represented in the Richardson coal and that are absent in the Princess No. 5 coal.

The assemblage reported earlier for the Princess No. 5 coal (table 1; fig. 3) is similar to that of the Richardson coal in that 20 of the 22 genera of the Princess No. 5 coal are present in the Richardson coal. Both Cristatisporites and Reinschospora are very rare and occur only in the seat rock of the Princess No. 5 coal. The seat rock of the Richardson coal at the type locality in the Milo quadrangle is reported to be a ganister and was not sampled by W. F. Outerbridge and E. C. Jenkins (written commun., Mar. 10, 1964). They reported the Richardson coal to consist of two benches, and they collected 12 samples to which maceration numbers 73 and 74 were assigned.

Macerations 13-A-C (D4605) contains coal and clay from the upper bench Richardson coal at the type locality located south-southwest of the gap labeled 1030 at lat $37^{\circ} 58^{\prime} 08.7^{\prime \prime}$ N., long $82^{\circ} 37^{\prime} 54.8^{\prime \prime}$ W., at an elevation of
1,010 feet at the base of the coal, Milo quadrangle, Kentucky.

73-A, 0.5 foot clay, semiflint;

$73-\mathrm{B}, 1.4$ feet coal;

$73-\mathrm{C}, 0.3$ foot seat rock, clay.

Macerations 74-A-I (D4606) contain coal and clay from the lower bench Richardson coal at the type locality located east-southeast of the gap labeled 1030 at lat $37^{\circ} 58^{\prime} 11.3^{\prime \prime} \mathrm{N}$., long $82^{\circ} 36^{\prime} 01.2^{\prime \prime} \mathrm{W}$., at an elevation of 975 feet at the base of the coal, Milo quadrangle, Kentucky. See table 8 for data on sampled units.

All three samples of the upper bench of the Richardson coal, maceration series 73 , failed to yield either abundant or well-preserved spores. Twenty-six genera have been identified from macerations $73-\mathrm{A}-\mathrm{C}$, but abundance counts have not been made because of poor yield and preservation. The same 26 genera are present in the lower bench of the Richardson coal (table 8), maceration series 74 . In addition to the genera reported for the Princess No. 5 coal, the following genera are present in the Richardson coal:
Alatisporites
Dictyotriletes
Knoxisporites
Radiizonates
Convolutispora
Reticulatisporites

A direct comparison of abundance between the Princess No. 5 coal and the lower bench Richardson coal is difficult at best because the Richardson coal is 8 times the thickness of the Princess No. 5. The Richardson coal at the type locality is basically a series of alternating coal and clay partings. Thus, we are comparing more than 88 inches of coal and clay from the lower bench Richardson coal with $93 / 8$ inches of coal from the Princess No. 5 coal. Despite this difference in thickness, a comparison with the numerically important genera of the Princess No. 5 can be made. The composited percentages for the seven coal-bearing samples 
TABLE 8. - Percentage of genera of small spores in the lower bench Richardson coal at the type locality, Milo quadrangle, Kentucky

\begin{tabular}{|c|c|c|c|c|c|c|c|c|c|}
\hline \multirow{2}{*}{$\begin{array}{l}\text { Genus } \\
\text { Maceration No. }\end{array}$} & \multicolumn{7}{|c|}{ Percent } & \multirow[b]{2}{*}{$74-\mathrm{H}$} & \multirow[b]{2}{*}{$74-1$} \\
\hline & $74-\mathrm{A}$ & $74-B$ & $74-\mathrm{C}$ & $74-D$ & $74-E$ & $74-F$ & $74-G$ & & \\
\hline Ahrensisporites___-_- & ---- & --- & --- & --- & ---- & ---- & 0.4 & ---- & + \\
\hline Alatisporites & ---- & ---- & + & - - - & ---- & 0.4 & + & ---- & + \\
\hline Calamospora & 0.4 & 0.8 & 0.4 & 2.8 & 0.4 & .4 & + & + & 2.0 \\
\hline Cirratriradites _-_-_- & .4 & + & .8 & .8 & .4 & .4 & .4 & ---- & .4 \\
\hline Convolutispora & --- & + & + & + & ---- & ---- & ---- & ---- & --- \\
\hline Crassispora & ---- & --- & ---- & ---- & ---- & .8 & .4 & ---- & + \\
\hline Densosporites & $-\ldots-$ & $-\ldots$ & ---- & 4.8 & $(?)$ & 1.6 & 14.0 & 2.8 & 3.6 \\
\hline Dictyotriletes & ---- & ---- & ---- & $-\ldots-$ & ---- & - - - & .4 & + & ---- \\
\hline Endosporites _-_--_- & 1.2 & --- & + & + & 1.2 & + & + & + & 6.4 \\
\hline Florinites _------- & 8.8 & 2.0 & 2.0 & 6.0 & 1.2 & 1.6 & .4 & .8 & 2.0 \\
\hline Granulatisporites --- & .4 & .8 & 2.8 & 9.6 & 5.6 & .8 & 4.0 & 5.2 & 4.4 \\
\hline Knoxisporites & ---- & + & ---- & + & --- & ---- & ---- & ---- & ---- \\
\hline Laevigatosporites _-_- & 15.2 & 80.4 & 28.0 & 38.0 & 44.4 & 36.4 & 22.4 & 30.4 & 32.8 \\
\hline Lycospora & 69.6 & 4.8 & 50.0 & 22.0 & 18.0 & 37.2 & 52.4 & 54.0 & 38.4 \\
\hline Murospora & ---- & ---- & $-\ldots-$ & + & $-\ldots-$ & ---- & ---- & ---- & ---- \\
\hline Punctatisporites _--_- & + & 2.0 & 1.2 & 1.6 & 1.6 & 3.6 & .8 & .8 & 4.4 \\
\hline Radiizonates _-_-_-- & ---- & ---- & $-\ldots-$ & $-\ldots$ & ---- & 1.2 & 1.2 & 2.0 & ---- \\
\hline Raistrickia _-_-_-_- & + & .4 & --- & .8 & + & .4 & + & .4 & + \\
\hline Reticulatisporites & ---- & + & ---- & .4 & .4 & + & + & ---- & .4 \\
\hline Savitrisporites _-_- & ---- & ---- & ---- & ---- & ---- & --- & + & ---- & --- \\
\hline Simozonotriletes _-_-_ & $-\ldots-$ & .4 & ---- & + & ---- & $-\ldots-$ & + & --- & ---- \\
\hline Torispora & 3.6 & 5.6 & 13.2 & 1.6 & 10.4 & 9.6 & 1.2 & 2.8 & .8 \\
\hline Triquitrites ___-_-_- & .4 & .8 & 1.6 & 9.2 & 14.8 & 2.8 & .4 & + & 3.2 \\
\hline Vestispora & ---- & + & ---- & .8 & .8 & .4 & .4 & + & + \\
\hline Wilsonites _--_---- & + & 2.0 & ---- & 1.2 & ---- & ---- & ---- & .8 & + \\
\hline Zosterosporites & --- & ---- & --- & ---- & ---- & ---- & + & ---- & --- \\
\hline Monosaccates _._. & $-\ldots$ & ---- & --- & ---- & ---- & 2.4 & 1.2 & ---- & .8 \\
\hline All other taxa & --- & + & ---- & .4 & ---- & + & + & + & .4 \\
\hline Total _._. & 100.0 & 100.0 & 100.0 & 100.0 & 100.0 & 100.0 & 100.0 & 100.0 & 100.0 \\
\hline
\end{tabular}

\section{DESCRIPTION OF MATERIAL IN MACERATIONS}

$74-\mathrm{A}, 0.4 \mathrm{ft}$ coal and clay. $74-\mathrm{B}, 0.1 \mathrm{ft}$ clay, roof of coal. $74-C, 0.8 \mathrm{ft}$ coal, $0.4 \mathrm{ft}$ clay.

$74-\mathrm{D}, 0.15 \mathrm{ft}$ coal, $0.1 \mathrm{ft}$ clay.
$74-\mathrm{E}, 0.9 \mathrm{ft}$ coal, $0.1 \mathrm{ft}$ clay.

$74-\mathrm{F}, 0.5 \mathrm{ft}$ coal, $0.6 \mathrm{ft}$ clay $74-\mathrm{G}, 1.35 \mathrm{ft}$ sandy roof clay $74-\mathrm{H}, 1.2 \mathrm{ft}$ coal

of the lower bench Richardson coal below, can be compared with the percentages for same genera of the Princess No. 5 coal (p. 3).

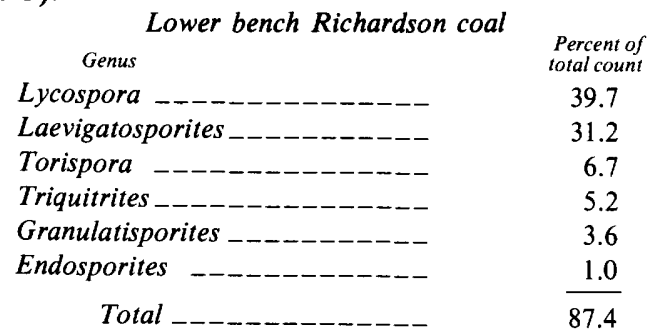

Clearly, Lycospora and Laevigatosporites are the most abundant genera in the Richardson coal, as in the Princess No. 5 coal, but their order of abundance is reversed.

Laevigatosporites punctatus constitutes 5.2 percent and
L. globosus - L. minutus represent 8.4 percent of the total assemblage. This is in the same range as their occurrence in the Princess No. 5 coal. For the most part, the species present in the Princess No. 5 coal are present in the Richardson coal. Several additional species occur in the Richardson coal, but perhaps their occurrence can be accounted for by the thickness of samples and the fact that most of the Richardson samples are a mixture of coal and clay. The sample of the Princess No. 5 coal could easily represent a part of the Richardson coal.

The type Skyline coal was collected by C. L. Rice and W. F. Outerbridge and submitted for analysis by Rice (Aug. 13, 1965). These samples were from 18,130 feet west and 21,070 feet north of the southeast corner of Tiptop quadrangle in eastern Kentucky. These samples were assigned maceration 
numbers $85-A-R$ (D4607). The total thickness of the samples is more than 200 inches, and 14 of the 18 samples contain coal that has an aggregate thickness of more than 170 inches. There are fewer partings in the Skyline coal than in the Richardson coal, and the samples were collected largely as single lithologic units. See table 9 for data on sampled units.

Laevigatosporites and Lycospora are the most abundant genera of the Skyline coal. For comparison with the Princess No. 5 and Richardson coals, the abundance of the following genera is recorded.

\begin{tabular}{|c|c|}
\hline Skyline coal & $\begin{array}{l}\text { Percent of } \\
\text { total count }\end{array}$ \\
\hline Laevigatosporites___-_-_-_-_-_ & 29.0 \\
\hline Lycospora _-_-_-_- & 27.5 \\
\hline Torispora _._._. & 9.4 \\
\hline Granulatisporites & 2.3 \\
\hline Triquitrites______-_-_ & 1.1 \\
\hline Endosporites _-_----_--- & 1.1 \\
\hline Total ___-_- & 70.4 \\
\hline
\end{tabular}

Neither Densosporites nor Radiizonates is numerically important as a member of the palynological assemblage of the Princess No. 5 coal or of the Richardson coal; however, these two genera represent 8 and 7 percent, respectively, of the total count in the Skyline coal. The occurrence of Radiizonates in the Skyline coal is very irregular. It may be abundant in one sample and totally absent in the next two or three samples. Twenty-five genera have been identified from samples of the Skyline coal (table 9), and all of these except Renisporites occur in either or both the Princess No. 5 coal and (or) Richardson coal. Renisporites occurs very sparsely in two Skyline samples.

Laevigatosporites punctatus is present as 3 percent of the total count in the Skyline coal samples. L. globosus $-L$. minutus constitute 9 percent in these samples. These abundance figures are compatible with those obtained from both the Princess No. 5 and the Richardson coals. Most of the significant species reported for the Princess No. 5 coal are present in the Skyline coal samples. Additional species oc-

TABLE 9. - Percentage of genera of small spores in the Skyline coal from the type locality

\begin{tabular}{|c|c|c|c|c|c|c|c|c|c|c|c|c|c|c|c|c|c|c|}
\hline Maceration No. _-_ & \multicolumn{18}{|c|}{ Percent } \\
\hline Ahrensisporites & $\ldots$ & --1 & - - & & & & & & -1 & --- & ---- & ----- & ---- & - & + & - - & - & $\ldots$ \\
\hline Calamospora _ & + & 1.6 & + & $\ldots$ & 0.4 & 0.8 & 0.4 & 1.2 & 1.6 & 0.8 & 0.8 & 0.8 & + & & --- & 0.4 & 1.6 & 1.6 \\
\hline Cirratriradites_ & $-\ldots-$ & .4 & 1.2 & 1.6 & .8 & + & .4 & .8 & + & .8 & + & .8 & 1.2 & 1.2 & + & + & 1.6 & + \\
\hline Convolutispora & $\ldots$ & $\ldots \ldots$ & $\ldots$ & $\ldots \ldots$ & $\ldots \ldots$ & .4 & .4 & + & -- & - & --- & --- & --- & + & $\ldots$ & + & + & + \\
\hline Dictyotriletes - & + & --- & + & + & + & .8 & .4 & $\ldots$ & + & $-\ldots$ & .4 & -- & 1.6 & - - - - & .4 & + & ---- & - \\
\hline Endosporites _ & .4 & 1.6 & .8 & + & - & -- & 2.0 & .4 & .4 & + & .4 & 5.2 & + & 2.4 & .4 & - & + & $\ldots$ \\
\hline Florinites _-_- & + & 2.0 & + & .4 & + & $\ldots$ & 1.6 & .8 & 1.2 & $\ldots$ & 1.2 & 4.8 & .8 & 2.4 & + & .4 & 4 & .4 \\
\hline Granulatisporites & 2.4 & 1.6 & .8 & 1.6 & 1.2 & 3.6 & 1.6 & 1.6 & 4.0 & 6.0 & 4.4 & .8 & 1.2 & 4.0 & 1.6 & 2.0 & 2.0 & 2.0 \\
\hline Laevigatosporites & 5.6 & 30.8 & 14.8 & 26.0 & 32.4 & 30.4 & 31.2 & 15.6 & 31.2 & 15.2 & 13.6 & 30.4 & 23.2 & 22.8 & 48.0 & 27.6 & 20.0 & 29.2 \\
\hline Lycospora & 80.4 & 41.6 & 38.8 & 7.2 & + & 3.2 & 35.2 & 67.6 & 49.2 & 40.4 & 50.0 & 50.8 & 5.6 & 16.0 & 24.8 & 54.0 & 67.6 & 62.4 \\
\hline Punctatisporites & + & 2.4 & 2.0 & 3.6 & .8 & 2.0 & 2.0 & 1.2 & 2.8 & 2.4 & 2.4 & .8 & 1.6 & .8 & 1.2 & 2.0 & .8 & .4 \\
\hline Reticulatisporites & $\begin{array}{l}---- \\
----\end{array}$ & $\begin{array}{l}--- \\
----\end{array}$ & .4 & .4 & + & + & + & .4 & + & & $\begin{array}{ll}--- \\
---\end{array}$ & & + & & + & + & + & + \\
\hline rites__ & $---\ldots$ & --- & -- & --- & --- & $\ldots$ & & & - & 3.2 & .4 & 4 & $\ldots \ldots$ & ---- & --- & $\ldots$ & -- & - \\
\hline Torispora _. & 2.0 & 6.0 & 18.0 & 22.0 & 27.6 & 9.6 & + & & 2.0 & 5.6 & + & .4 & 13.2 & 5.6 & 12.0 & 4.8 & 2.0 & .8 \\
\hline Triquitrites _-_ & .8 & 3.2 & + & + & .8 & + & .8 & .8 & 2.4 & 18.4 & 12.4 & .8 & + & ---- & ---- & .4 & 1.2 & 2.4 \\
\hline Vestispora & + & .8 & --- & 2.0 & $\ldots$ & ---- & + & .4 & 1.6 & + & 3.2 & .8 & + & .4 & + & 1.2 & 1.2 & + \\
\hline Wilsonites _ _. & $-\ldots--$ & $---\ldots$ & $\ldots$ & + & 1.2 & $-\ldots$ & + & .4 & --- & 1.2 & 2.0 & ---- & & ---- & .4 & .4 & $-\ldots--$ & + \\
\hline Zosterosporites & ---- & -- & -- & -- & + & -- & i. & $\ldots$ & - - & -- & & ---- & $\ldots$ & ---- & --- & 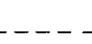 & ( & - \\
\hline Monosaccates _ & 1.6 & 1.2 & .4 & 2.0 & 2.4 & .4 & --- & 1.6 & .4 & 2.8 & 3.6 & ---- & $\ldots$ & --- & -- & & & .4 \\
\hline All other taxa - & + & --- & .8 & .8 & .4 & $\ldots$ & --- & + & -- & -- & + & ---- & 1.2 & ---- & + & - & - & - \\
\hline Total __ - & 100.0 & 100.0 & 100.0 & 100.0 & 100.0 & 100.0 & 100.0 & 100.0 & 100.0 & 100.0 & 100.0 & 100.0 & 100.0 & 100.0 & 100.0 & 100.0 & 100.0 & 100.0 \\
\hline
\end{tabular}

DESCRIPTION OF MATERIAL IN MACERATIONS

$85-\mathrm{A}, 14$ inches silty carbonaceous shale.

$85-\mathrm{B}, 161 / 4$ inches coal, bone at base.

$85-C, 8$ inches carbonace

$85-\mathrm{D}, 171 / 2$ inches coal.

$85-\mathrm{F}, 15^{3 / 4}$ inches coal.

$85-\mathrm{F}, 15 \%$ inches coal.
$85-\mathrm{G}, 10$ inches coal.

$85-$ H, $3^{3 / 4}$ inches coal-shale-coal.

$85-\mathrm{H}, 3 \% / 4$ inches coal
$85-\mathrm{I}, 12$ inches coal.
$85-\mathrm{J}, 6$ inches silty shale.

$85-\mathrm{K}, 4^{1 / 4}$ inches coal with $1 / 2$ inch clay.

$85-\mathrm{L}, 18^{3 / 4}$ inches coal.

$85-\mathrm{M}, 13$ inches coal.

$85-\mathrm{N}, 11$ inches coal.
$85-\mathrm{O}, 131 / 2$ inches coal.

$85-\mathrm{O}, 13 \frac{1}{2}$ inches coal.
$85-\mathrm{P}, 15$ inches coal.

$85-\mathrm{P}, 15$ inches coal.
$85-0,9$ inches coal.

$85-Q, 9$ inches coal.
$85-\mathrm{R}, 3$ inches underclay. 
cur in the Skyline coal, and this is not unexpected when difference in thickness is considered: $93 / 8$ inches coal (Princess No. 5) and more than 170 inches of coal (Skyline).

The lower bench Richardson coal could very easily correlate with part of the Skyline coal, and Princess No. 5 coal already discussed could correlate with part of the Richardson coal. Certainly, the palynological evidence indicates a proximity in time.

Two coals occurring between the Princess No. 5 coal and the Vanport Limestone Member are the Princess Nos. 5A and 5B coals. These have been discussed by Ferm (1963, p. 48). Coals of equivalent age elsewhere in eastern Kentucky are unknown. Whether correlatives of the Nos. 5A and 5B coals exist in adjacent States is not known.

The palynological assemblage of the two thin samples of the Lawrence coal is dominated by Lycospora, according to Gray (1967). Gray's composite abundance figures for these two coal samples show that 65 percent of the assemblage is Lycospora, 16.2 percent is Laevigatosporites, and 5.7 percent is Punctatisporites. Laevigatosporites globosus represents 9 percent of the assemblage, or more than half the total for that genus. L. minutus and L. punctatus are present in minor amounts. No $L$. pseudothiessenii was reported in the Lawrence coal.

The Lawrence coal, occurring between the Vanport Limestone Member, below, and the Lower Kittanning coal, above, does not correlate with the Princess No. 6 coal. Actual interpretation of the palynological information is difficult because of the limited information available. In the Princess reserve district there is a marked tendency for the abundance of Lycospora to decline, starting with the Princess 5B coal, and for the abundance of Laevigatosporites to increase. Initially, Laevigatosporites globosus - L. minutus increase in abundance as Lycospora declines, and this is followed by a significant increase in Laevigatosporites pseudothiessenii from the Princess No. 6 through No. 7 coals.

Wanless (1939) correlated the Nos. 6-9 coals of northeastern Kentucky with the Lower and Middle Kittanning coals and Lower and Upper Freeport coals of Pennsylvania and Ohio.

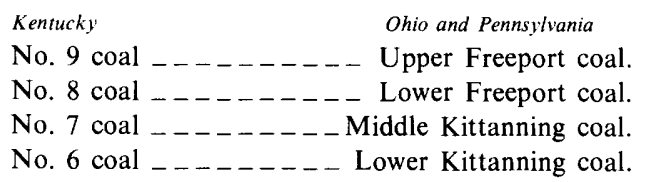

In more recent years, because of studies of the coal reserves of eastern Kentucky by Huddle, Lyons, and Ferm (1963) and the cooperative mapping project between the Kentucky Geological Survey and the U.S. Geological Survey, much more information on the lateral extent of the Princess coals is available. The younger Pennsylvanian beds from the Princess No. 7 coal and above are exposed in the Greenup, Ironton, Argillite, Boltsfork, Rush, Webbville, and Fallsburg quadrangles. Dobrovolny, Sharps, and Ferm
(1963) correlated the Princess Nos. 6 and 7 coals of northeastern Kentucky with the Lower and Middle Kittanning coals of eastern Ohio, and questionably assigned the Princess No. 8 coal to the Lower Freeport coal.

A comparison of the palynological analyses of the Princess No. 6 coal from eastern Kentucky with those of the Lower Kittanning coal by Gray (1967) from eastern Ohio and western Pennsylvania suggests a relationship in generic and specific content and, to a somewhat lesser extent, in abundance. Schopfites dimorphus, Laevigatosporites pseudothiessenii or Thymospora pseudothiessenii, Vesicaspora wilsonii, and Spackmanites ellipticus are all a part of the Lower Kittanning-Princess No. 6 assemblage. Furthermore, Laevigatosporites and Lycospora are the most abundant members of the assemblage. Laevigatosporites globosus-L. minutus compose 28 percent according to Gray (1967). Gray examined eight collections of the Lower Kittanning coal, including samples from the type area. These percentages are similar to the composite percentages of the Princess No. 6 coal. Examination of text figures 5 and 6 of Gray (1967) shows extreme variation in the abundance ratios of Laevigatosporites, Lycospora, and Densosporites in the Lower Kittanning coal. Samples from the type area in Armstrong County, Pa. (Dutcher and others, 1959) contained the following numerically significant genera on a composite basis: Lower Kittanning coal

\begin{tabular}{lrrr}
\hline & \multicolumn{3}{c}{ Percent of total count } \\
\cline { 2 - 4 } Genus & $\begin{array}{c}\text { Composite } \\
1299-\mathrm{A}-\mathrm{C}\end{array}$ & $1299-\mathrm{A}$ \\
\hline Laevigatosporites & 43.2 & 60.0 \\
Lycospora & 20.9 & 3.0 \\
Punctatisporites & 9.2 & 3.5 \\
Densosporites & 6.9 & 20.0 \\
Florinites & & 5.3 & 2.5 \\
\hline & & 85.5 & 89.0 \\
\hline
\end{tabular}

The composite for the numerically significant genera of the Lower Kittanning coal from the type area (Gray, 1967, maceration ser. $1299-\mathrm{A}-\mathrm{C})$ is similar to that of the Princess No. 6 coal (maceration ser. 238-F-H) described earlier in this report, even to the abundance of Densosporites in the top sample (1299-A). Gray reported on seven other collections of the Lower Kittanning coal, and only two of these, located 140-160 miles north-northeast of Ashland, Ky., will be mentioned to demonstrate the variations in abundance ratios. Maceration series 1357 from Tuscarawas County, Ohio, apparently lacks representatives of Densosporites, and Lycospora is nearly as abundant as Laevigatosporites. The coal is reported to be 1 foot 5 inches thick without partings. Maceration series 1331 from northern Coshocton County, Ohio, contains Lycospora as the dominant genus (about 57 percent) followed in abundance by Densosporites (about 15 percent) and Laevigatosporites (about 11 percent). The coal at this locality is 2 feet 10 inches thick without partings. 
The second set of samples of the Princess No. 6 coal from eastern Kentucky (maceration ser. 161-A-I, table 5) has already been discussed. Note, however, that Densosporites triangularis is present but not abundant in the bottom two coal samples. There is reasonable evidence to conclude that the Princess No. 6 coal and the Lower Kittanning coal are related. Palynological differences exist from western Pennsylvania into eastern Kentucky, but these differences are minor. The plants, as reflected by their recoverable spores and pollen grains, are basically the same.

Habib's (1966) investigation of the Lower Kittanning coal from western Pennsylvania was an effort to delineate the palynological assemblage or assemblages and relate this information to biological, physical, and chemical properties of the coal and adjacent strata. The palynological assemblage reported by Habib (1966) and Gray (1967) for the Lower Kittanning coal is similar to that of the Princess No. 6 coal from eastern Kentucky. Also, Habib recognized in his samples plant succession or a changing flora from bottom to top, culminating in what he termed the "Densosporites oblatus assemblage" in 7 of the 15 sets of samples. Habib reported five "assemblages" from the Lower Kittanning coal, starting with the Lycospora assemblage at the bottom and terminating with the Densosporites oblatus assemblage. These five "assemblages" are Densosporites oblatus, Punctatisporites obliquus, Thymospora pseudothiessenii, LycosporaGuthoerlisporites, and Lycospora.

Habib concluded that assemblages characterized by Densosporites oblatus and Punctatisporites obliquus in the top part of the Lower Kittanning coal are overlain by marine facies. This facies is an unnamed shale unit occurring above the coal and is not the Lower Kittanning Shale, which occurs below the Lower Kittanning coal. According to Habib, where fresh-water facies are directly over the coal, the assemblage is dominated throughout by assemblages rich in Lycospora. In essence, if Habib is correct, Densosporites oblatus (which is similar if not related to $D$. triangularis) and Punctatisporites obliquus are saline-tolerant plants to some degree. Perhaps other plants of these same assemblages should also be regarded as saline tolerant if they are consistently present. This surely would include Laevigatosporites globosus, other species of the genus, and, in some samples, even Lycospora. Whether these spores were derived from an in situ saline community or were carried to this location from a nonsaline environment is not known. The occurrence of a marine fauna within the coal depositional phase of sedimentation in the United States has been demonstrated by Mamay and Yochelson $(1953,1962)$. Regardless of the explanation for the presence of marine invertebrates during the closing stages of peat (coal) deposition, a marine environment may have been present there or nearby. It is difficult to measure the influence of a transgressive marine environment on coal deposition other than postulating cessation of coal deposition or a drastic change in flora composition.

Smith (1962, 1964) and Smith and Butterworth (1967) have considered the occurrence and implication of plant succession in seat earths, coal, and roof shales in the British Isles. Smith (1962) recognized several successive spore associations in British coals, which he termed "phases." The first phase, occurring at the bottom of the coal, is the Lycospore phase, in which the coal is typically bright. Next occurs the Transition phase, which is characterized by various species of Laevigatosporites and by coal that is intermediate between the bright, Lycospore phase below and the dull, Densospore phase above. If peat formation continued beyond the Densospore phase, the Lycospore phase returned and occurs adjacent to the roof. A fourth phase, the Incursion phase, was recognized, and it may occur at any point in the bed. This phase is thought to be partly the result of a fresh-water incursion over the peat surface, and the species associated with this phase often include those common to the Lycospore and Transition phases.

The environmental conditions which favor the phase changes or plant succession were considered to be complex by Smith and Butterworth (1967). They believed that the conditions favoring the formation of the Densospore phase were specialized. A prerequisite for the formation of this phase, according to Smith and Butterworth, was peat accumulation of some thickness, together with a subsequent reduction in water cover. If subsidence resulted in a fairly constant depth of water over the peat, they believed that a Lycospore or an Incursion phase was likely to occur.

Smith, Habib, and their associates agree that Densosporites commonly occurs late in any given coal depositional sequence and under special environmental conditions. However, they do not agree as to the cause of the development of the Densosporites assemblage or phase. In other words plant succession - or the replacement of one community with another - is readily recognized, but the causal factors are not completely understood.

The present study on the Princess coals is not especially suited to the evaluation of the causal factors of plant succession or the lateral variations in spore-pollen assemblages in relation to the roof rock. It does seem worthwhile, though, to examine the data in light of the studies by Habib (1966) and Gray (1967). The Princess No. 5 coal (maceration ser. 238-Y-CC) does not contain Densosporites, except for scattered occurrences in the lower part of the bed and in the seat rock. Torispora securis is abundant in the parting and at the top of the coal. Densosporites is present only in the seat rock of the Princess No. 5A coal (maceration ser. 238-P-X). The Princess No. 5B coal does contain 8.4 percent Densosporites in the bottom coal sample. Both samples of the Princess No. 6 coal $(238-E-I, 161-A-I)$ contain Densosporites, largely $D$. triangularis, as shown in tables 4 and 5. The abundance and distribution of Densosporites in 
the samples from the Webbville quadrangle is similar to that reported by Habib (1966) and Gray (1967) for some of their samples. The top sample of coal contains 16.8 percent Densosporites. Evidence that a marine transgression is responsible for the abundance of Densosporites in the top one-third of the coal bed is lacking. The roof shale sample, $238-\mathrm{E}$, is only $4 \frac{1}{8}$ inches thick, it is noncalcareous, and it contains poorly preserved plant megafossils. Plant microfossils are abundant, and Laevigatosporites globosus is dominant. Carlson (1971) reported a shale roof and siltstone, neither of which is marine. A thin crystalline limestone is commonly present midway between the Princess Nos. 6 and 7 coals. In summary, the presence of Densosporites, constituting 16.8 percent of the assemblages, in the top coal samples apparently is not associated with a marine roof shale.

The other sample of the Princess No. 6 coal from Rush quadrangle contains only 4.4 percent Densosporites in one of the lower segment samples. Carlson (1965) in his report on the Rush quadrangle reported that a roof shale and siltstone was commonly present, but no data indicate that they are marine. He did report that a limestone is present midway between the Princess Nos. 6 and 7 coals. The limestone contains Spirorbis, a genus of serpulid worms known to have a broad range of tolerance, from salt to virtually nonmarine conditions. Densosporites is at the terminus of its coal range zone in the Princess No. 7 coal and is just barely represented in samples from the Webbville quadrangle.

The Middle Kittanning coal as reported by Gray (1967) has Laevigatosporites as the overall dominant genus (59.1 percent), and Lycospora is next in numerical importance (24.8 percent). Laevigatosporites globosus is the most abundant species, constituting 37.1 percent of the assemblage, and $L$. minutus constitutes 4 percent of the assemblage. These two species represent 41.1 percent of the assemblage of the Middle Kittanning coal. These same two species represent 40.5 and 35.8 percent of the assemblage of the Princess No. 7 coal (maceration ser. 160 and 238-A-D). Laevigatosporites pseudothiessenii represents 14.6 percent of the composite spore count of the Middle Kittanning coal, according to Gray (1967). This species represents nearly 21 percent of the assemblage of the Princess No. 7 coal (maceration ser. 160) and twice this amount in the thin sample of the Princess No. 7 coal (maceration ser. 238-A-D). Laevigatosporites clearly is the dominant genus in the Princess No. 7 coal. The palynologic assemblage of the Princess No. 7 coal is similar to that of the Middle Kittanning coal, as reported by Gray (1967). The largest difference between the assemblage reported for the Middle Kittanning coal, by Gray (1967), and the assemblage of the Princess No. 7 coal is that Laevigatosporites, although dominant in both coals, is more abundant in the Princess No. 7 coal. All the numerically important, or abundant, genera and species are common to both coals. Parasporites maccabei Schopf is present in the Princess No. 7 coal (table 7, 160-D). This taxon was described by Schopf (1938) from the Carbondale Formation of Illinois, Ferm (1950) reported Parasporites from some samples of the Middle(?) Kittanning coal from Beaver County, Pa. Mamay and Yochelson (1962) recorded Parasporites from the well-known Berryville coal-ball locality in Illinois. Winslow (1959) reported that Parasporites was not abundant and that it was sparsely dispersed in Illinois coals, ranging from the Rock Island (No. 1) through the "Divide" coals. This interrupted range zone would be from the Spoon Formation to the Mattoon Formation (of Kosanke and others, 1960). I have observed Parasporites from the Carbondale Formation of western Kentucky. There is little doubt about the similarity of the assemblages of the Princess No. 7 and the Middle Kittanning coals; as a result, a correlation between these two coals seems to be reasonable.

\section{INTERREGIONAL COAL CORRELATIONS}

Interregional coal correlations between the Appalachian and Eastern Interior basins were proposed by Wanless (1939), Weller (in Wanless, 1939), and Moore and others (1944). Wanless correlated the Middle and Lower Kittanning coals of the Appalachians, respectively, with the Herrin (No. 6) and Colchester (No. 2) coals of Illinois, whereas, Weller correlated the Upper Freeport and Middle Kittanning coals of the Appalachians with the Herrin (No. 6) and Colchester (No. 2) coals of Illinois. Wanless (1939) reported, "The writer has relied on partings in the Upper Delong and Herrin (No. 6) coals in his correlation, but neither of these match coals with widespread partings in Weller's correlation. Paleontologic and physical evidence seem to conflict, paleontologic evidence favoring Weller's correlation and physical evidence favoring that of the writer." The partings in the Delong coal were compared to the partings of the Fire Clay coal of eastern Kentucky even though they were not a flint clay. Moore (1944) adopted Wanless' correlations for the Middle and Lower Kittanning coals.

In the past, palynologists - including myself (1947) have been reluctant to attempt interregional correlations. This reluctance is understandable, and the same philosophy perhaps should apply at the present time. However, I have decided that an appraisal should be made of the facts at hand - either to establish correlations or to more clearly appreciate the problems.

The range zone of Schopfites in the Appalachian basin is from the Lower through Middle Kittanning coals, according to Gray (1967), and I have observed spores of this genus in both Princess Nos. 6 and 7 coals of northeastern Kentucky. So far as is known, then, the entire range zone covers a span of about 50 feet, as shown in figure 6. In Illinois, Peppers (1970) reported that Schopfites occurs in two thin coals below the Colchester (No. 2) coal through the Briar Hill 


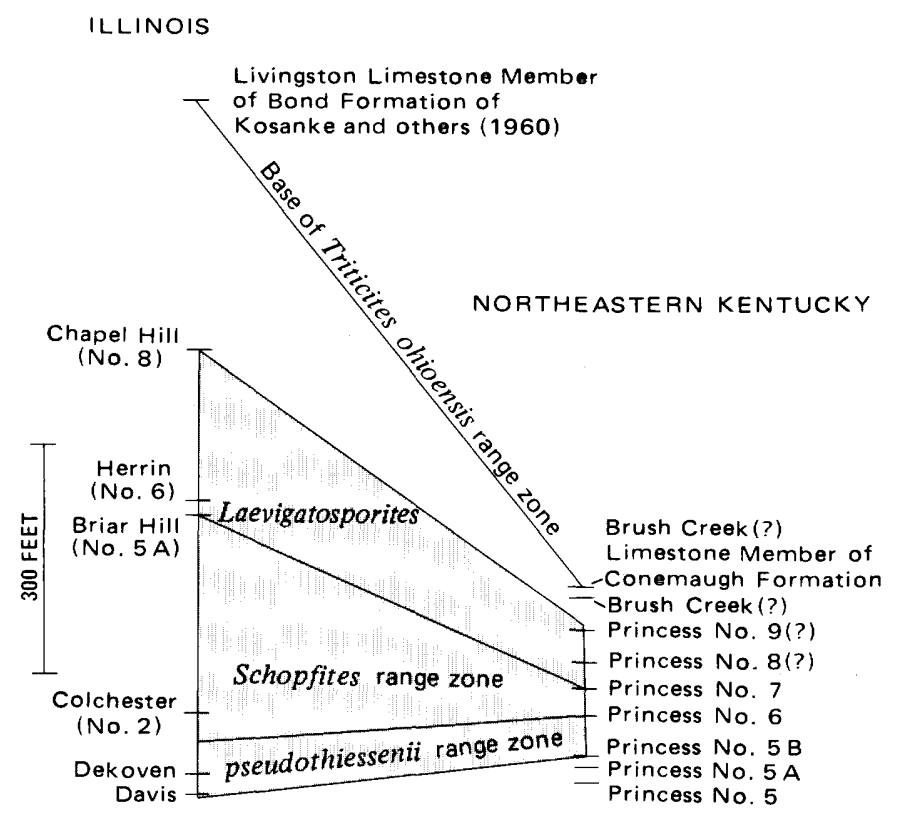

Figure 6. - The range zones of two spore taxa from Illinois are contrasted with the same range zones in northeastern Kentucky, together with the base of the range zone of the fusulinid tax on Triticites ohioensis, as projected from Ohio into Kentucky. All stratigraphic units other than members are coals. The Schopfites range zone used in this paper refers to Pennsylvanian occurrences in Illinois and eastern United States. For additional discussion, see Kosanke (1969, p. 233).

(No. 5A) coal. In other words, the range zone of Schopfites in the Eastern Interior basin covers approximately 300 feet, as compared with about 50 feet in the Appalachian basin. Laevigatosporites pseudothiessenii is present in the Princess No. 5B seat-rock sample and in the Princess Nos. 6-9(?) coal samples (163 maceration ser.). This would be about 175 feet in northeastern Kentucky, as shown in figure 6. Gray (1967) reported this species to be not from the Lawrence coal but from the Lower Kittanning, Strasburg, and Middle Kittanning coals. In Illinois $L$. pseudothiessenii is present from the Davis coal to the Chapel Hill (No. 8) coal, or through about 600 feet of section, as shown in figure 6 . The range zones of these two taxa at this time indicate much greater deposition in Illinois than in the Appalachians. In Illinois the range zone of Schopfites spans an intervat of some 300 feet that contains as many as seven coals and three limestones as contrasted with an interval of less than 50 feet, in Ohio, that contains the Middle Kittanning coal, Salem Limestone Member, Strasburg coal, Hamden Limestone Member, and Lower Kittanning coal - all the Allegheny Formation of Stout $(1918,1924)$. In northeastern Kentucky the range zone of Schopfites spans less than 50 feet and contains the Princess Nos. 6 and 7 coals with a limestone between the two coals in some areas. The range zones of both Schopfites and Laevigatosporites pseudothiessenii form a remarkably similar pattern, as shown in figure 6 .

Thompson (1936) described Triticites ohioensis from the Brush Creek Limestone Member of the Conemaugh Forma- tion of Ohio. This is the basal unit of the range zone of $T$. ohioensis. Weller, Henbest, and Dunbar (1942) reported this species present in the Livingston Limestone Member of the Bond Formation in Illinois, which is the lowest known occurrence of this species in Illinois. The Livingston Limestone Member is about 325 feet above the Chapel Hill (No. 8) coal in Illinois and is plotted in figure 6. The base of the range zone of $T$. ohioensis is shown from the Livingston Limestone Member in Illinois to the Brush Creek(?) Limestone Member in northeastern Kentucky. In figure 6 the slope of the line connecting the Livingston Limestone Member with the Brush Creek(?) Limestone Member is similar to, and perhaps slightly more inclined than, the lines representing the top of the range zones of Laevigatosporites pseudothiessenii and Schopfites.

From the published works of Habib (1966), Peppers (1970), Kosanke $(1947,1950,1964)$ and the present investigation, it seems reasonable to correlate the Colchester (No. 2) coal of Illinois with the Lower Kittanning coal of Pennsylvania and Ohio, together with the Princess No. 6 coal of northeastern Kentucky. Palynological evidence supports the correlation of Wanless (1939). It is also clear that the Princess No. 7 coal is related to the Middle Kittanning coal, and, if Wanless (1939) is correct, the assemblage of this coal should resemble that of the Herrin (No. 6) coal of Illinois. Certainly, there are similarities, both qualitatively and quantitatively, along with some exceptions.

Many genera and species are common to both the Herrin (No. 6) coal and the Middle Kittanning-Princess No. 7 coal. Two exceptions that should be discussed are the occurrence of Schopfites and Densosporites in the Middle Kittanning-Princess No. 7 coal. These taxa do not occur in the Herrin (No. 6) coal of Illinois. Although in the Princess No. 7 coal these taxa represent significantly less than 1 percent of the total assemblage, this discrepancy requires further consideration. In Illinois, Kosanke (1950) and Peppers (1970) reported that the Schopfites range zone terminates with the Briar Hill (No. 5A) coal just below the Herrin (No. 6) coal. On face value, the Middle Kittanning-Princess No. 7 coal cannot be younger than the Briar Hill (No. 5A) coal and may correlate with the Springfield (No. 5) coal of Illinois. Peppers (1970) reported that the Middle Kittanning coal more closely resembles the Springfield (No. 5) coal than it does the Herrin (No. 6) coal.

Another seemingly anomalous occurrence is the presence of Densosporites in the Middle Kittanning-Princess No. 7 coal, inasmuch as the genus is not known to occur above the Lowell coal in Illinois. This could be considered by some to be a greater discrepancy than the previous example, but I do not consider it as such. I have observed Densosporites in noncoal samples up to the Des Moinesian-Missourian boundary of the midcontinent area; thus, the potential for incorporation into a swamp deposition is present. Consideration should be given at this time to the Strasburg coal of Ohio, located stratigraphically between the Lower and 
Middle Kittanning coals. Gray (1967) reported on two samples of the Strasburg coal. Qualitatively, the assemblage reported by Gray for the Strasburg coal is similar to that of both the Lower and the Middle Kittanning coals. Quantitatively, the two samples of the Strasburg coal are vastly different. However, one of the two samples is only 3 inches thick, so this sample should not be considered for the present, except that it might represent a small portion of the Strasburg coal. The other sample of the Strasburg coal (maceration ser. 1214) is reported to be 22 inches thick and is regarded as being more representative. Quantitatively, it more closely resembles the Middle Kittanning coal than it does the Lower Kittanning coal, in that Laevigatosporites represents 60 percent of the assemblage. Three abundant species are L. globosus, L. minutus, and L.pseudothiessenii.

A comparison of abundance ratios between the Herrin (No. 6) coal of Illinois and the Princess No. 7 coal reveals little similarity because Laevigatosporites is much more abundant in the Princess No. 7 coal. A much closer comparison based on abundance ratios can be made between the Springfield (No. 5) coal of Illinois and the Princess No. 7 coal. However, more samples need to be examined in detail to determine the full range of abundance variation of the Princess No. 7 coal. Additionally, productive samples of both the Princess No. 8 and the Princess No. 9 coals are required to be absolutely certain of several important range zones. From the information available, it is possible to say that the Middle Kittanning-Princess No. 7 coal more than likely is not older than the Springfield (No. 5) coal, and it might be as young as the Briar Hill (No. 5A) coal of Illinois.

\section{SUMMARY}

The palynological contents of the Princess No. 5, 5A, 5B, 6 , and 7 coals have been determined. Poor recovery and preservation have limited the palynological information obtained from younger coals in the Princess reserve district. From the Princess No. 5 to the Princess No. 7 coal the Lycospora-Laevigatosporites-dominated assemblage changes to an assemblage dominated by Laevigatosporites. This change is the result of a significant numerical increase in L. globosus and L. pseudothiessenii. The latter species has a range zone from the Princess No. 5B coal through the Princess No. 9(?) coal, whereas Schopfites apparently is restricted to the Princess Nos. 6 and 7 coals. The top of the range zone of Densosporites is the Princess No. 7 coal. Zosterosporites is a new genus and $Z$. triangularis is reported present in the roof rock of the Princess No. 5 coal and the seat rock of the Princess 5B coal. A limited number of specimens assignable to this genus have been observed in the Fire Clay rider and Francis coals lower in the Breathitt Formation. The suggested correlation of the Princess No. 5 coal with the Richardson and Skyline coals by Huddle, Lyons, and Ferm (Huddle and others, 1963) is feasible. The correlation of the Princess Nos. 6 and 7 coals with the
Lower and Middle Kittanning coals is confirmed. Wanless' (1939) correlation of the Lower Kittanning-Princess No. 6 coal with the Colchester (No. 2) of Illinois also seems reasonable. The Middle Kittanning-Princess No. 7 coal assemblage is similar to that of the Springfield (No. 5) coal, although it might be as young as the Briar Hill (No. 5A) coal of Illinois.

\section{REFERENCES CITED}

Carlson, J. E., 1965, Geology of the Rush quadrangle, Kentucky: U.S. Geol. Survey Geol. Quad. Map GQ-408.

1971, Geologic Map of the Webbville quadrangle, eastern Kentucky: U.S. Geol. Survey Geol. Quad. Map GQ-927.

Dobrovolny, Ernest, Sharps, J. A., and Ferm, J. C., 1963, Geology of the Ashland quadrangle, Kentucky-Ohio, and the Catlettsburg quadrangle in Kentucky: U.S. Geol. Survey Geol. Quad. Map GQ-196.

Dutcher, R. R., Ferm, J. C., Flint, N. K., and Williams, E. G., 1959, The Pennsylvanian of western Pennsylvania, Field trip 2, in Geol. Soc. America, Guidebook for field trips, Pittsburgh meeting, 1959: p. $61-114$.

Ferm, J. C., 1950, Megaspores of the Middle(?) Kittanning coal in Beaver County, Pennsylvania [abs.]: Am. Jour. Botany, v. 37, no. 8, p. $672-673$.

1963, Coal beds of the Princess reserve district, in Part 3 of Coal reserves of eastern Kentucky, by J. W. Huddle, E. J. Lyons, H. L. Smith, and J. C. Ferm: U.S. Geol. Survey Bulletin 1120, p. 32-55.

Gray, L. R., 1967, Palynology of four Allegheny coals, northern Appalachian coal field: Palaeontographica, ser. B, v. 121, nos. 1-3, p. $65-86$.

Gray, L. R. and Taylor, T. N., 1967, Palynology of the Schulztown coal in western Kentucky: Trans. Am. Microsc, Soc., v. 28, no. 4, p. 502-506.

Guennel, G. K., 1952, Fossil spores of the Alleghenian coals in Indiana: Indiana Geol. Survey Rept. Prog. 4, 40 p. 1958, Miospore analysis of the Pottsville coals of Indiana: Indiana Geol. Survey Bull. 13, $101 \mathrm{p}$.

Habib, Daniel, 1966, Distribution of spore and pollen assemblages in the Lower Kittanning coal of western Pennsylvania: Palaeontology, v. 9, pt. 4, p. 629-666.

Habib, Daniel, and Groth, P. K. H., 1967, Paleoecology of migrating Carboniferous peat environments: Palaeography, Palaeoclimatology, Palaeoecology, v. 3, no. 1, p. 185-195.

Huddle, J. W., Lyons, E. J., and Ferm, J. C., 1963, Geology and geography of the eastern Kentucky coal field, Part 2 of Coal reserves of eastern Kentucky, by J. W. Huddle, E. J. Lyons, H. L. Smith, and J. C. Ferm: U.S. Geol. Survey Bulletin 1120, p. 14-31.

Kosanke, R. M., 1947, Plant microfossils in the correlation of coal beds [IIl.], in Wanless, H. R., Symposium on Pennsylvanian problems: Jour. Geology, v. 55 , no. 3, pt. 2, p. 280-284.

1950, Pennsylvanian spores of Illinois and their use in correlation: Illinois Geol. Survey Bull. 74, 128 p.

1964, Applied Paleozoic palynology, in Palynology in oil exploration - A symposium, San Francisco, Calif., 1962: Soc. Econ. Paleontologists and Mineralogists Spec. Pub. 11, p. 75-89.

1969, Mississippian and Pennsylvanian palynology, chap. 12, in Tschudy, R. H., and Scott, R. A. eds., Aspects of palynology: WileyInterscience, A division of John Wiley \& Sons, New York, p. $223-269$

Kosanke, R. M., Simon, J. A., Wanless, H. R., and Willman, H. B., 1960, Classification of the Pennsylvanian strata of Illinois: Illinois Geol. Survey Rept. Inv. 214, 84 p.

Mamay, S. H., Yochelson, E. L., 1953, Floral-faunal associations in American coal balls: Science, v. 118, no. 3061, p. 240-241. 
1962, Occurrence and significance of marine animal remains in American coal balls; U.S. Geol. Survey Prof. Paper 354-1, p. $193-224$.

Moore, R. C., chm., and others, 1944, Correlation of Pennsylvanian formations of North America: Geol. Soc. America Bull., v. 55, p. $657-706$.

Peppers, R. A., 1970, Correlation and palynology of coals in the Carbondale and Spoon Formations (Pennsylvanian) of the northeastern part of the Illinois basin: Illinois Geol. Survey Bull. 93, $173 \mathrm{p}$.

Schemel, M. P., 1951, Small spores of the Mystic coal of lowa: Am. Midland Naturalist, v. 46, no. 3, p. 743-750.

Schopf, J. M., 1938, Spores from the Herrin (No. 6) coal bed in Illinois: Illinois Geol. Survey Rept. Inv. 50, 73 p.

Smith, A. H. V., 1962, Paleoecology of Carboniferous peats based on miospores and the petrography of bituminous coals: Proc. Yorkshire Geol. Soc., v. 33, p. 423-475.

1964, Zur Petrologie und Palynologie der Kohlenflöze der Karbons und ihrer Begleitschichten: Fortschr. Geologie Rheinland, v. 12, p. $285-302$.
Smith, A. H. V., and Butterworth, M. A., 1967, Miospores in the coal seams of Great Britain: London, Palaeont. Assoc., Palaeontology Special Paper 1, $324 \mathrm{p}$.

Stout, Wilber, 1918, Geology of Muskingum County [Ohio]: Ohio Geol. Survey Bull. 21, 4th ser., 351 p.

1924, Geology of Columbiana County [Ohio]: Ohio Geol. Survey Bull. 28, 4th ser., $408 \mathrm{p}$.

Thompson, M. L., 1936, Pennsylvanian Fusulinids from Ohio: Jour. Paleontology, v. 10 , no. 8, p. $673-683$.

Wanless, H. R., 1939, Pennsylvanian correlations in the Eastern Interior and Appalachian coal fields: Geol. Soc. American Spec. Paper 17, $130 \mathrm{p}$.

Weller, J. M., Henbest, L. G., and Dunbar, C. O., 1942 Stratigraphy of the fusuline-bearing beds of Illinois, in Dunbar, C. O., and Henbest, L. G., Pennsylvanian Fusulinidae of Hllinois: Illinois Geol. Survey Bull. 67, p. 9-34.

Winslow, M. R., 1959, Upper Mississippian and Pennsylvanian megaspores and other plant microfossils from Illinois: Illinois Geol. Survey Bull. 86, 135 p. 


\section{INDEX}

[Italic page numbers indicate major references]

A, B

Abstract

Abundance counts, taxa in samples

additus, Triquitrites spp -

Alatisporites _._-_-__-_-_-_-_-_ 6, 8, 9, 12,13, 14

hexalatus__._.

trialatus _-_._-

annulatus, Cirratriradites _-__-_-_-_-_-_-_-_-_

antiquus, Florinites --

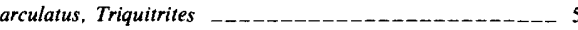

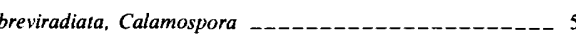

Briar Hill (No. 5A) coal _._-_._- 17, 18, 19

Brush Creek(?) coal _-_-

Cadiospora

Calamospora breviradiata

hartungiana _._._._._-_-____._._._.

spp _-_-_-_________- 5

Cirratriradites _._. annulatus _-_.-_-

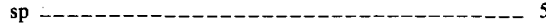

Coal correlations, interregional _____ Princess coals -_-_-_-_-_-_-_-_-_-_-_12

Colchester (No. 2) coal _______- 7, 9,17,18, 19

Convolutispora _.__________-_ 6, 8, 9, 11, 12, 13, 14 sp -_____._.

Correlations, interregional, coal _Princess coals -_.

Crassispora _._._._._._._._. 3, 6, 8, 9, 11, 13, 14

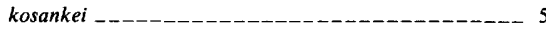

crinita, Raistrickia -

Cristatisporites _-___-___-_ 3, 8, 9, 12

sp - -

crocea, Raistrickia

D

delicatus, Wilsonites

Delong coal

Densosporites _- 3, 5, 6, 8, 9, 10,11, 13,14, 15, 16, 17, 18, 19 oblatus _-__-__ triangularis _-__-_______-__-_- 5, 9, 16

desmoinensis, Laevigatosporites

Dictyotriletes

- 12, 13, 14

Dichorites _-_________-_-_-_-_--- 5, 15

District name, origin _-_-_-_-_-_- 1

E, F

ellipticus, Spackmanites __________-_ 5, 9, 15 Endosporites ___ 3, 6, 8, 9, 11, 13, 14 ornatus _-_-_-_-_-_-_-_-_-_-_-_-_-_- 5

sp - -

exiguus, Triquitrites

fenestrata, Vestispora

Fire Clay coal _-_-_-_-_-_-_-_-_-_-_- 17

Florinites _............ 3, 6, 8, 9, 11, 13, 14 antiquus _-_-__sp _-
Page

gibbosus, Granulatisporites

globosus, Laevigatosporites $5,7,10,13,14,15,16,17,19$; pl. 1

granularis, Granulatisporites _-__-_-_-_-_-_-_- 5

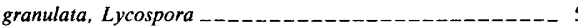

Granulatis

$3,6,8,9,11,13,14$

gibbosus

pallidus

spinosus -- - - - -

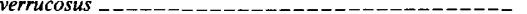

spp - - - - -

Guthoerlisporites

$\mathrm{H}, \mathrm{I}, \mathrm{K}$

hartungiana, Calamospora

Herrin (No. 6) coal hexalatus, Alatisporites _______-____-_-_ 5,7

Interregional correlations, coal _-_-__-_-__- 17 inusitatus, Triquitrites _._._._- 5 Investigations, previous work

Knoxisporites

12,13

kosankei, Crassispora

Murospora

12,13

$\mathbf{L}$

Laboratory maceration numbers See also specific coal names.

Laevigatosporites _-_ 3, 6, 8, 9, 10,11, 13, 14, 15, 16, 17, 19 desmoinensis _._. globosus _._. $5,7,10,13,14,15,16,17,19$; pl. 1

latus

medius _._-_.

minutus _-_-_-_-_ 5, 7, 10,13,14, 15, 17, 19; pl. 1 ovalis pseudothiessenii _-_- $5,7,9,10,15,17,18,19 ;$ pl. 1 punctatus vulgaris

Lawrence coal _-....

levis, Granulatisporites

Localities, paleobotanical, numbers _._._-_______._ 2 sample

Location, Princess reserve district _._-_____-_-_- 1 roadcut where samples were taken _-_______ 1,10 Webbville 1 diamond-drill hole _._._._._._... 1, 2

Lowell coal

Lower Freeport coal _-_._-_-_-

Lower Kittanning coal correlation _._________ $15,17,18,19$ numerically important genera

Lycospora _-__- 3, 6, 8, 9, 10,11, 13,14,15, 16, 17, 19 granulata _-_. micropapillata _-_-_-_-_-_-_-_-_-_----- 5 pseudoannulata _-___-__-_-_-_-_-_-_-_-_ 5 punctata sp _._-_._._._._.

maccabei, Parasporites $-5,17$

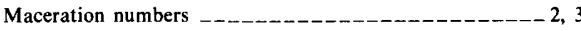
Maceration residues, mounting _-______._-_-_- 3 medius, Laevigatosporites _-_-_-_-_-_-_-_-_-_-_ 5 micropapillata, Lycospora
Middle Kittanning coal _-___-_____ 9, 15, 17, 18, 19 minutus, Laevigatosporites _- 5, 7, 10, 13, 14, 15, 17, 19; pl. 1 Punctatisporites - Monosaccates __._._._._._._- 3, 6, 8, 9, 11, 13, 14

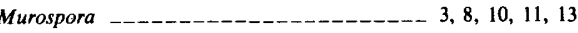
kosankei

$\mathrm{N}, \mathrm{O}$

nux, Savitrisporites _-_-

oblatus, Densosporites obliquus, Punctatisporites _-_ohioensis, Triticites _-_-_-_-_-_-_ 18 ornatus, Endosporites _-_______-__-__-_-_- 5

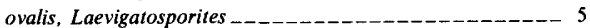

$\mathbf{P}$

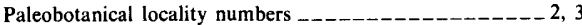

pallidus, Granulatisporites _-..-

Palynologic assemblages, Princess coals___-_-___-_-_ 3 See also specific coal names.

Parasporites _-_..-_ 11, 17 maccabei Percentage of genera of small spores, Princess No. 5 coal Princess No. 5A coal Princess No. 5B coal _________-_ 8 Princess No. 6 coal (drill core) -_-_-_-_-_-_- 8 Princess No. 6 coal (roadcut) Princess No. 7 coal _____-__-__-_-_-_-_-_ 11 Richardson coal _._._-______ 13 Skyline coal _._-_-_-_- 14

Potonieisporites -_-_-_-_-_-_-_-_- 8 sp - -

Preparation, mounting of maceration residues _-_-_-_---- 3

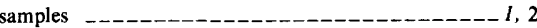

Princess coals, correlation

Princess No. 5 coal ________________ 1, 2, 3, 5

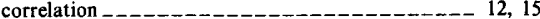
generic comparison with Richardson coal________-_ 13 generic comparison with Skyline coal _-_-_-_-_-- 14 generic comparison with $5 \mathrm{~A}$ coal _._._-___._- 6,9

numerically important genera _-_._-_._-_-_._- 3 Zosterosporites triangularis ____________-_-_-_ 11

Princess No. 5A coal correlation__________- 15, 19 generic comparison _.________- 7, 8, 9, 16 numerically important genera _-_-_-_-_-_-_-_- 6

Princess No. 5B coal ____ 1, 3, 6, 7 correlation__-__-_-_-_ 15, 16, 18 numerically important genera _._.___.______- 6 percentage of genera of small spores _._._._-_-_ 8 Zosterosporites triangularis _-_-_-_-_- 11

Princess No. 6 coal _._.________._. 1, 3, 7 correlation _._._.

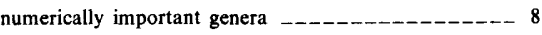
percentage of genera of small spores

Princess No. 7 coal _._. 1, 3, 7, 9, 10 correlation _.___._._._._. 15, 17, 18, 19 numerically important genera _-_._-_._.-- 10 percentage of genera of small spores Princess No. 8(?) coal _-__-_-_-_-_ 3, 10, 15, 19 Princess No. 9(?) coal ___________ 3, 7, 10, 15, 19 protensus, Triquitrites _-_-_-_-_-_-_-_-_-_-_-_-- 5 pseudoannulata, Lycospora 
Page

pseudothiessenii. Laevigatosporites 5, 7, 9, 10, 15, 17, 18, 19; pl. 1 Thymospora _- 5, 15, 16; pl. 1 pulvinatus, Triquitrites _-__-_-_-_-_-_-_-_-_-_ 5 Punctatisporites minutus _-___-______. 1

obliquus __-__-__-_ 5, 16

sulcatus _-__spp

punctata, Lycospora _-_._._-_-_-_-_- 5

punctatus, Laevigatosporites _._-_- 5, 6, 10,13, 14, 15; pl. 1

\section{$\mathbf{R}$}

Radiizonates _Raistrickia _._._._.___ 3, 6, 8, 9, 11, 13, 14 crinita -_-_-_-_-_-_-_-______._._-_- 5

$-5$

spp _...-

Reinschospora _-_-_-_-_-_-_-_-_-_- 3, 12, 14

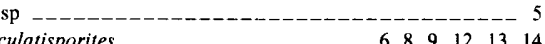

sp _-_-_-_-_-_-_- 5

Richardson coal _._-_-_-_-_-_-_-_-_ 11, 12, 14, 15 numerically important genera Zosterosporites triangularis __.____________ 11

Samples, localities

preparation -

Webbville 1 diamond-drill hole

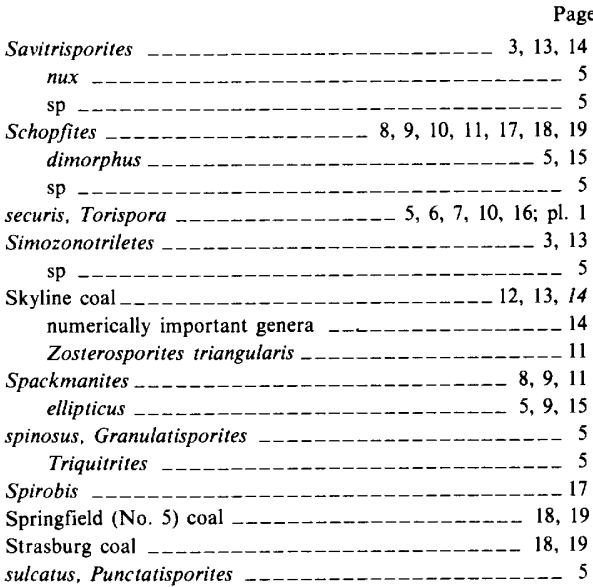

W, Z

Webbville 1 diamond-drill hole _-_._____ 1, 2, 6, 10 wilsonii, Vesicaspora

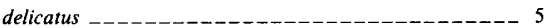
spp --_-_-_-_-

Zosterosporites _-___-__-______ 3, 8, 10,13,14, 19 triangularis _... 


\section{PLATE 1}

[Contact photograph of the plate in this report is available, at cost, from the U.S. Geological Survey Photographic Library, Federal Center, Denver, Colorado 80225] 


\section{PLATE 1}

FIGURES 1-6. Zosterosporites triangularis, n. gen., n. sp. USGS paleobotanical loc. D4599-C.

1. Holotype, maceration $238-O$, single grain mount $1,108.9 \times 14.5$, proximal focus, maximum diameter 29.7 microns and negative number 1969.

2. Holotype, distal focus and negative number 1792.

3. Paratype, maceration $238-0$, slide $2,103.1 \times 11.0$, proximal focus, maximum diameter 29.7 microns and negative number 1752 .

4. Paratype, maceration $238-0$, slide $5,109.7 \times 7.7$, proximal focus, maximum diameter 31 microns and negative number 1973 .

5. Paratype, maceration $238-\mathrm{O}$, slide $3,111.9 \times 12.0$ distal focus, maximum diameter 27.0 microns and negative number 1771 .

6. Paratype, maceration $238-\mathrm{O}$, slide $5,109.4 \times 8.3$, distal focus, maximum diameter 32.4 microns and negative number 1793 .

7. Laevigatosporites globosus Schemel, D4600, maceration $161-\mathrm{F}, 121.3 \times 9.8$, proximal focus from distal side, maximum diameter 27 microns and negative number 1803.

8. Laevigatosporites pseudothiessenii Kosanke = Thymospora pseudothiessenii (Kosanke) emend. Wilson and Venkatachala, D4601, maceration $160-\mathrm{E}$, slide $11,112.3 \times 6.0$, oblique proximal view, maximum diameter 40.5 and negative number 1808 .

9. Laevigatosporites minutus (Ibrahim) S. W. \& B. = Punctatosporites minutus Ibrahim, D3302, maceration 5-B, slide $18,107.0 \times 0.0$, oblique proximal view, maximum diameter 25.0 microns and negative numberr 1807 .

10, 12. Torispora securis Balme.

10. D4599-C, maceration $238-\mathrm{O}$, slide $6,102.6 \times 17.5$, oblique proximal view, maximum diameter 40.5 , microns and negative number 1759 .

12. D4599-A, maceration $238-\mathrm{Z}$, slide 4 , $112.4 \times 7.2$, oblique proximal view, maximum diameter 41.8 microns and negative number 1773 .

11. Laevigatosporites punciatus Kosanke, D4599-C, maceration $238-\mathrm{O}$, single grain mount $6,119.9 \times 9.7$, proximal view, maximum diameter 40.5 microns and negative number 1759 . 


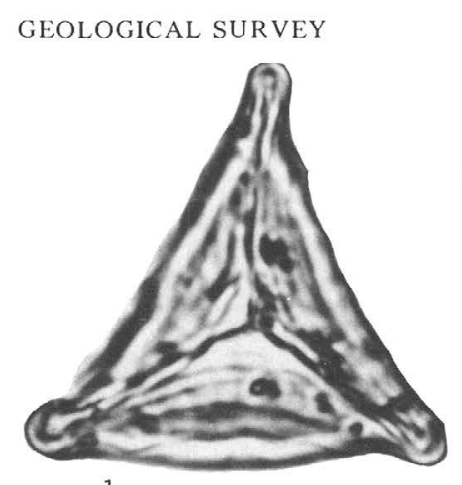

1
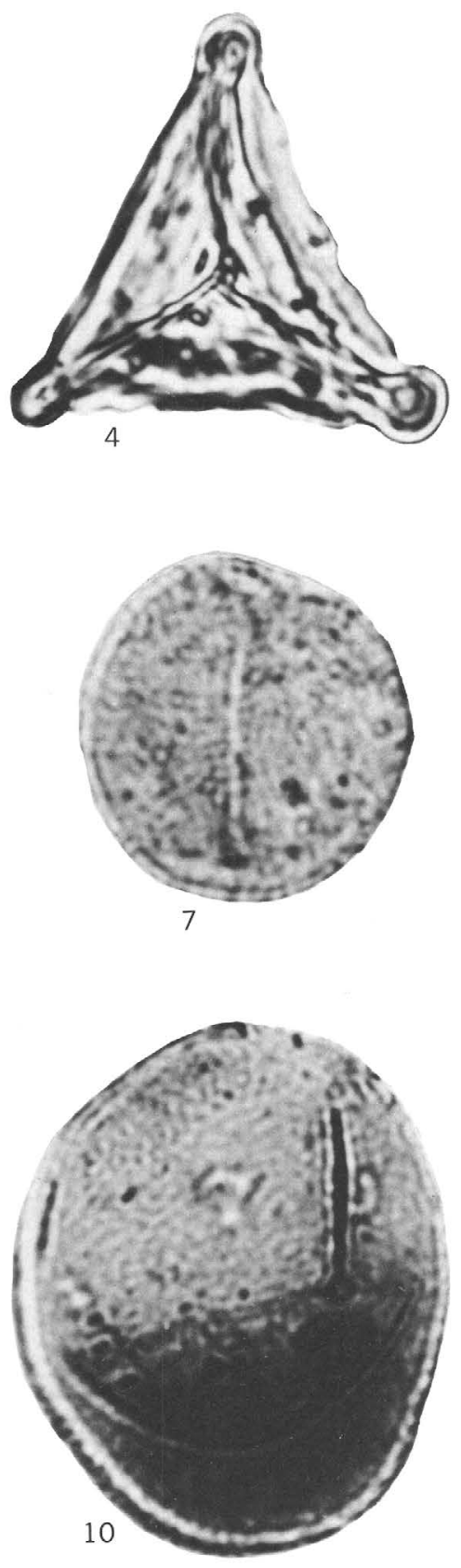
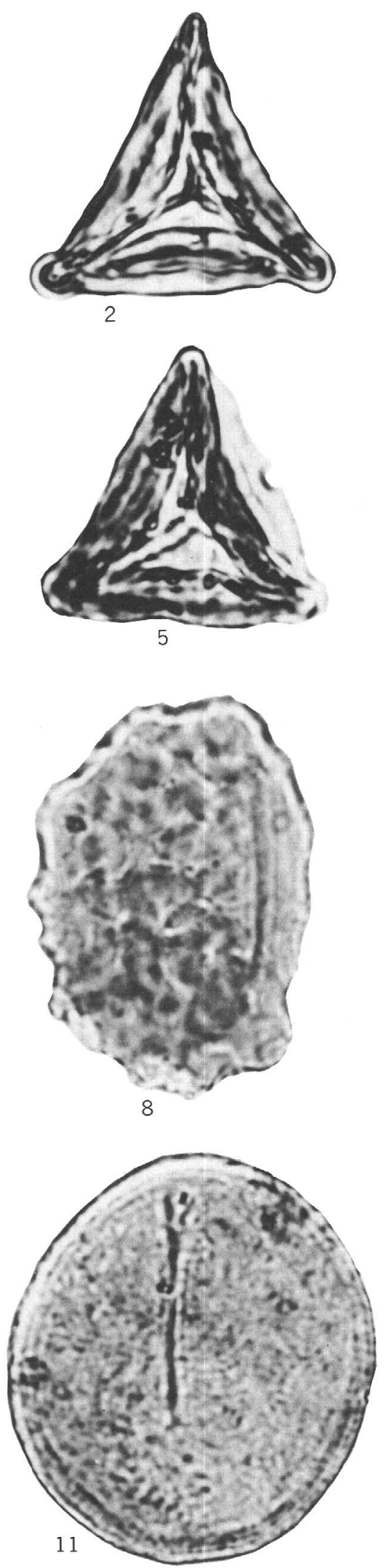

PROFESSIONAL PAPER 839 PLATE 1
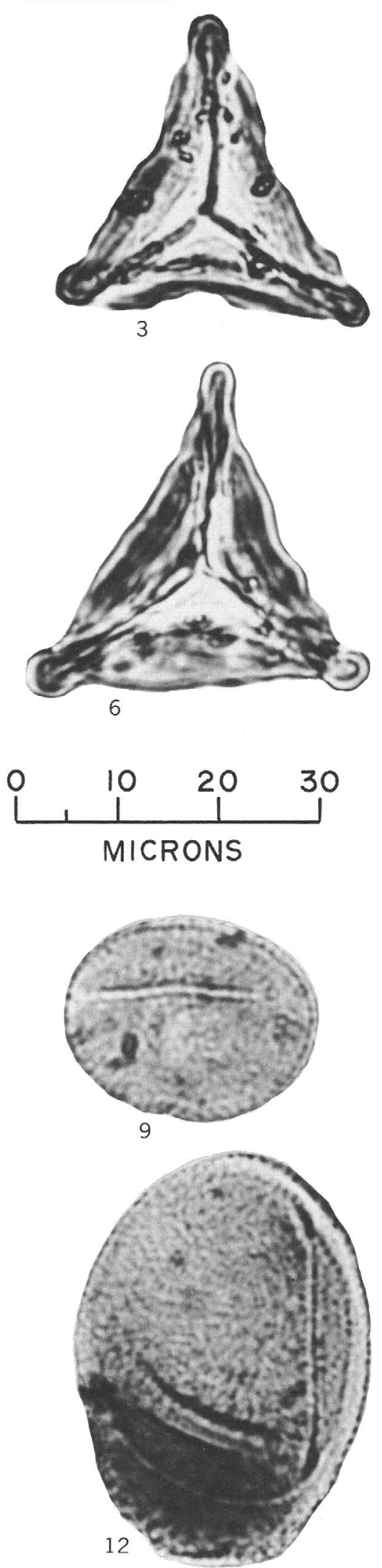

ZOSTEROSPORITES, LAEVIGATOSPORITES, AND TORISPORA 
